\author{
Jarosław Bodzek, Szymon Jellonek, Barbara Zając \\ https://doi.org/10.26485/AAL/2019/65/5
}

\title{
ROMAN PROVINCIAL COINS FOUND IN LESSER POLAND: AN OVERVIEW ${ }^{1}$
}

\begin{abstract}
The aim of the present article is to summarize a current state of research on the problem of inflow of Roman provincial coins into Lesser Poland in antiquity. The term "provincial coinage" as used here refers to coins from the mints producing coinages for the purpose of provincial circulation, as well as to the so-called pseudo-autonomous and autonomous coinages struck by various local mints. We consider coins produced in mints located in the Eastern part of the Roman Empire, beginning from Dacia and Moesia, and farther east and south to the provinces of Asia Minor, Syria, and Egypt as well as these struck by the rulers of the Bosporan Kingdom. The chronological scope of this presentation is defined by the final decades of the Roman Republic/the beginning of the Roman Empire and the Diocletian's reform (AD 294). We shall concentrate on the relevant finds of bronze coinage and the so-called billon coins. Only one brief paragraph is devoted to silver issues.
\end{abstract}

Keywords: Barbaricum, Bosporan Kingdom, coins, Lesser Poland, Roman provincial coinage

ABSTRAKT Celem niniejszego artykułu jest podsumowanie aktualnego stanu badań na temat napływu monet prowincjonalnych zarejestrowanych na obszarze historycznej Małopolski. Pod pojęciem „mennictwa prowincjonalnego" rozumiane są tutaj zarówno monety prowincjonalne bite w mennicach produkujących monety na użytek danej prowincji, jak i tzw. monety pseudoautonomiczne i autonomiczne bite w mennicach lokalnych. W niniejszym tekście uwzględnione zostały monety produkowane w mennicach zlokalizowanych we wschodniej części Cesarstwa Rzymskiego poczynając od Dacji i Mezji, i położonych dalej na Wschód i Południe aż po prowincje w Azji Mniejszej, Syrię i Egipt, jak również monety bite przez władców Królestwa Bosporańskiego. Ramy chronologiczne niniejszych rozważań wyznaczają końcowe dziesięciolecia Republiki / początek Cesarstwa oraz reforma Dioklecjana (294 r. n.e.). Pod uwagę zostały wzięte przede wszystkim znaleziska monet brązowych i tzw. bilonowych. Jedynie krótki akapit poświęcony został monecie srebrnej.

Słowa kluczowe: Barbaricum, Królestwo Bosporańskie, monety, Małopolska, prowincje, rzymskie mennictwo prowincjonalne

1 The present publication has been made possible thanks to the financial support from the National Programme for the Development of Humanities of the Ministry of Science and the Higher Education - grant no. 0047/NPRH2/ H11/81/2012 ("Finds of Roman coins from the territory of Poland and the lands historically connected with Poland") (FRCPL). The original version of the text was presented at the conference "Money and banks in Lesser Poland," co-organized and held by the National Museum in Krakow and the National Museum in Poznań. The authors wish to acknowledge Dr Kiryll Myzgin from the University of Warsaw, Dr hab. Arkadiusz Dymowski, and Dr Tomasz Więcek for their assistance in collecting material for this article and their valuable comments. We would also like to offer thanks to the following people for providing us with photographs of: Prof. Renata Madyda-Legutko and Dr Joanna Telega-Zagórska from the Institute of Archaeology, Jagiellonian University; Dr hab. Jacek Górski, director of the Archaeological Museum of Krakow; Robert Ślusarek, M.A., director of the Regional Museum in Nowy Sącz; Bartłomiej Urbański, M.A. from the Regional Museum in Nowy Sącz; Włodzimierz Kisza, M.A. from the Jagiellonian University Museum, Krakow and Andrzej Szpunar, M.A., director of the Regional Museum in Tarnów, Agnieszka Kukułka from the Regional Museum in Tarnów and Marcin Rudnicki, M.A. 
Finds of Roman coins arriving into the territory of present-day Poland in Antiquity have been a subject of thorough research for several decades. Over the last several years in particular (2013-2018), such discoveries have been recorded in greater numbers on account of the project entitled Finds of Roman coins from the territory of Poland and the lands historically connected with Poland (FRCPL) under the direction of Prof. Aleksander Bursche from the University of Warsaw and with the funds from the National Programme for the Development of Humanities of the Ministry of Science and the Higher Education. ${ }^{2}$ The historical territories of Lesser Poland are one of the areas within the framework of this project. ${ }^{3}$ Among the thousands of records that document the finds of Roman coins in Lesser Poland as part of the FRCPL project, there is also a small group of Roman provincial coins dating from the Imperial period. ${ }^{4}$ The present article is an attempt to recapitulate the current state of our knowledge on the discoveries of this type from the territory of Lesser Poland. The term "provincial coinage" as used here refers to provincial coins in the strict sense of this designation, i.e., those from the mints producing coinages for the purpose of provincial circulation (e.g., Alexandria in Egypt), as well as to the so-called pseudo-autonomous and autonomous coinages struck by various local mints (e.g., Olbia Pontica). In the present text, we have taken into consideration coins produced in mints located in the Eastern part of the Roman Empire, beginning from Dacia and Moesia, and farther east and south to the provinces of Asia Minor, Syria, and Egypt. Likewise, we have included the coinage struck over a period from the $1^{\text {st }}$ century $\mathrm{BC}$ to the $4^{\text {th }}$ century $\mathrm{AD}$ by the rulers of the Bosporan Kingdom, even though these are not, strictly speaking, Roman provincial coins. At least in theory, the chronological scope of this presentation is defined by the final decades of the Roman Republic/the beginning of the

2 Cf. Bursche 2013; Idem 2014. Supplementary to the FRCPL was the project under the direction of Arkadiusz Dymowski "Money of the Roman Republic in Central Europe" (grant no. DEC-2013/09/D/HS3/04515 of the National Centre for Science).

3 The region of Lesser Poland has been the subject of research work carried out by the team under Dr hab. J. Bodzek, with Dr K. Kopij, Dr K. Lach, Dr E. Smagur, J. Kliś, M.A., B. Zając, M.A., Sz. Jellonek, M.A., and P. Koczwara, M.A. as members. For the preliminary results, see Bodzek et al. 2014; Bodzek, Kopij, Smagur 2017; Bodzek, Jellonek, Zając 2018.

4 For the provincial coinage, cf. Jones 1963; Idem 1965; Butcher 1988; Howgego 2005; Amandry 2012.
Roman Empire and the complete discontinuation of provincial coinage with the advent of Diocletian's reform (AD 294), ${ }^{5}$ although, on the other hand, the Bosporan Kingdom continued to mint coins until almost as late as mid- $4^{\text {th }}$ century AD. ${ }^{6}$ In the course of the present article, we shall concentrate on the relevant finds of bronze coinage and the so-called billon coins. Only one brief paragraph is devoted to silver issues.?

45 years ago, the eminent scholar Prof. Andrzej Kunisz published a comprehensive analysis of the so-called autonomous coins from the Imperial period as found in the territories of Central and Eastern Europe (a special issue of Wiadomości Numizmatyczne / Polish Numismatic News II, 1973). ${ }^{8}$ Considering the author's thorough and indepth treatment of the subject and the quality of the publication, it is no surprise that no one has since then attempted to revisit this subject matter in such a scope. ${ }^{9}$ A notable exception is a study by Dr Stanisława Kubiak, published several years later, on the finds of Greek coins in the territory of Poland, which also covers some discoveries of Imperial-era provincial coinage, ${ }^{10}$ but this publication, now more than 35 years old, does not reflect our current state of knowledge. In the meantime, we have also seen a handful of works that include some finds of the relevant type as recorded in specific regions or within the areas associated with particular archaeological cultures of the Centraland Eastern-European Barbaricum, namely by such authors as Georgiy Beidin, ${ }^{1}$ Aleksander Bursche, ${ }^{12}$ Renata Ciołek, ${ }^{13}$ Dragan Milutinović, ${ }^{14}$

5 Howgego 2005: 16.

6 Cf. Frolova 1997; Anokhin 1986

7 It is worth mentioning here that the discoveries of Greek coins struck before the end of the $1^{\text {st }}$ century BC were discussed in detail against the backdrop of Northern, Central, and Eastern Europe in a number of works by M. Mielczarek. Cf. above all Mielczarek 1989; a list of the older literature is available here; cf. also Idem 1981; Idem 1988; Idem 1996; Idem 2004; Idem 2008.

8 Kunisz 1973b.

9 In this context, let us also mention the study by A. Bursche (1984). Although it is an important publication commenting on the inflow of provincial coins into the space of the Central-European Barbaricum, it gives no information referring to any new material.

10 Kubiak 1978.

11 Beidin 2012; Beidin, Myzgin 2015.

12 Bursche 1983; Idem 1984; Idem 1988; Idem 1996; Idem 1997; Bursche, Kaczanowski, Rodzińska-Nowak 2000.

13 Ciołek 2001; Idem 2007; Idem 2008.

14 Milutinović 2015. 
Arkadiusz Dymowski, ${ }^{15}$ Piotr Kaczanowski and Urszula Margos, ${ }^{16}$ Stanisława Kubiak, ${ }^{17}$ Renata Madyda-Legutko, ${ }^{18}$ Kiryll Myzgin, ${ }^{19}$ Andrzej Romanowski, ${ }^{20}$ Vital Sidarovich, ${ }^{21}$ as well as by the authors of the present text. ${ }^{22}$ However, we still do not have a current, reliable, and comprehensive research study dedicated to this topic, even though it is very much needed in view of the amount of new material obtained and collected in the course of the last 45 years, coming from both random discoveries and the regular archaeological research. In the case of the territories of the CentralEuropean Barbaricum, the amassed material is not particularly abundant, but still definitely sufficient for undertaking a new insight into the subject in question..$^{23}$ On the other hand, a very large body of recent finds of provincial coinage in the wide area of the Eastern-European Barbaricum, the result of very intense activity of the so-called detectorists from Ukraine and Russia, cannot be ignored. ${ }^{24}$

As we have noted, this article aims to sum up the up-to-date state of our knowledge on the finds of provincial coinage as reported from the area of the historical region of Lesser Poland. The latter term is understood to refer to Lesser Poland in the boundaries as defined by Andrzej Kunisz in his inventories of the finds of Roman coins, which would comprise the modern-day voivodeships (provinces): Lesser Poland, Subcarpathian, Holy Cross (Świętokrzyskie) as well as parts of the Silesian, Łódź, and Lublin voivodeships..$^{25}$ Likewise, we do not omit references to the data on some relevant

15 Dymowski 2011 and a number of articles that record coin finds from various regions of present-day Poland.

16 Kaczanowski, Margos 2002; Kaczanowski 2017.

17 Kubiak 1978; Idem 1979.

18 Madyda-Legutko 1997.

19 Myzgin 2015a; Idem 2015b; Idem 2017; Idem 2018; Myzgin, Beidin 2012; Idem 2015.

20 Romanowski 2008.

21 Sidarovich 2014.

22 Bodzek 2004; Bodzek, Madyda-Legutko 1997; Idem 2013; Idem 2018; Zając 2017.

23 At the present time, Dragan Milutinović, M.A. (Institute of Archaeology of the University of Wrocław) has been working on his doctoral dissertation on the presence of provincial coinage in the Barbaricum. In anticipation of the results of his work, we shall have, most likely in a few years' time, a new study on the problem of the inflow of provincial coins into the territory of Central-European Barbaricum.

24 Cf. Myzgin 2018.

25 Kunisz 1969; Idem 1985. finds from the neighbouring regions. ${ }^{26}$ Such references are significant on account of the anachronistic, from the perspective of Antiquity, character of the notion "Lesser Poland".

Leaving out the details of cultural transformations and putting this issue in more general terms, it should be said that in the first four centuries AD, a major part of the historical Lesser Poland, specifically, its western, northern, central, and south-eastern areas were settled by the Przeworsk culture identified with the tribes of the Lugian Federation (known from some ancient sources), but also with the Germanic Vandals. ${ }^{27}$ Only the north-eastern fragment of Lesser Poland came within the settlement area of the "Gothic" population associated with the Wielbark culture and the so-called Masłomęcz group. ${ }^{28}$ As we know, the settlement areas of these two cultures are not limited to Lesser Poland. To put it more broadly, the range of the Przeworsk culture would also cover Silesia and central Poland to the west of the Vistula, while the Wielbark culture would also extend to Pomerania and the terrain at the right bank of the Middle Vistula (valley). The culture situation in the southern, (sub-)Carpathian section of the territory under consideration is not entirely clear, with two possible contributing factors: infiltration from the Przeworsk culture and the influence coming from the lands farther south. ${ }^{29}$ It is quite obvious that taking the culture divisions into account in an analysis of Roman coin finds is of significance, although a more generally conceived analysis cannot be underestimated as it might allow one to formulate some more comprehensive conclusions concerning the arrival of coins.

Finds of silver coins, i.e., Cappadocian, Lycian, and Pontic drachmae, from the territories of the Barbaricum, but also from the Roman Empire, constitute a distinct question as compared with discoveries of bronze and billon coins. To date, several publications have been dedicated to this subject. ${ }^{30}$ Very few finds representing this type have so far

26 The present text does not aspire to give a complete updated list of such finds coming from outside of the region of Lesser Poland. Such an extensive treatment of this subject would reach beyond the scope of our article.

27 For further bibliography, cf. Maciałowicz, Rudnicki and Strobin 2016, esp. 152; Kontny 2016, esp. 169f; Rodzińska-Nowak 2016.

28 Cf. Kokowski 1995; Idem 1999; Cieśliński 2016.

29 Cf. Madyda-Legutko 1995; Idem 1996a; Idem 1996b; Madyda-Legutko, Poleski, Krąpiec 2005.

30 Kunisz 1979; Idem 1983; Bodzek 2004; Bogucki, Jurkiewicz, Machajewski 2012; Zając 2017. Cf. also Bar 1985. 
been reported from Lesser Poland. One drachma of Amisos in the name of Hadrian comes from the hoard Nietulisko Małe II (Ostrowiec Świętokrzyski County), ${ }^{31}$ while Lycian drachmae of Trajan ( 2 pieces) were recorded as part of a hoard of denarii found at Wojków (Mielec County) in the year $1885^{32}$ as well as in the hoard of Żulice (Tomaszów Lubelski County) ${ }^{33}$ (2 pieces). In addition, one Cappadocian drachma, also in the name of Trajan, is known from the hoard Nietulisko Małe I (Ostrowiec Świętokrzyski County; P1. 1.1). ${ }^{34}$ Such coin finds have also been reported from locations situated more to the north, from the settlement areas of the Przeworsk and Wielbark cultures. These are primarily pieces found as part of hoards. Some drachmae of Amisos minted in Hadrian's reign had been found in the hoards of Drzewicz Nowy (Żyrardów County) ${ }^{35}$ and, probably, of Krzewica (Biała Podlaska County), ${ }^{36}$ whereas a Lycian drachma of Trajan was among the coins in a hoard from Ossa-Rywałdzik (Nowe Miasto Lubawskie County). ${ }^{37}$ Single finds of such coins are much less often found. The case in point here is a Lycian drachma of Trajan unearthed on the settlement site of the Przeworsk culture at a locality called Łęki Majątek (Kutno County). ${ }^{38}$ A Cappadocian drachma of Caracalla, found in the environs of Piaseczno (Łęczna County), should fall within the same category. ${ }^{39}$ To these pieces, we should also add some unidentified silver coins with Greek inscriptions which are known from

31 Kunisz 1985: 148, 160. II, no. 396; Mitkowa-Szubert 1989; Kaczanowski, Margos 2002: 203ff, no. 500 .

32 Anonymous 1916: 60; Kunisz 1985: 246f, no. 309 I, 3; Kaczanowski, Margos 2002: 347, no. 853; Zając 2017.

33 Kunisz 1985: 258f, no. 338, 260; Mielniczuk 1997: 261, 263f, 278, no. 93; Feduszka 1999: 78, no. 60; Paszkiewicz 1999: 103-104; Kaczanowski, Margos 2002: 366ff, no. 921; Zajacc 2017: 968, note 16 .

34 Bodzek 2004; Kaczanowski, Margos 2002: 156ff, no. 499.

35 Kunisz 1973b: 28f, no. 22; Krzyżanowska 1976: 74, no. 1080, tab. XLVI; Kubiak 1978: 208, no. 62; Kubiak 1979: 29ff, no. 25.

36 Kunisz 1973b: 57, no. 7; Kubiak 1978: 209, no. 65; Kubiak 1979: 53, no. 57; Romanowski 2008: 53, no. 86. 3 .

37 Anonymous 1936: 156; Kunisz 1973a: 79, no. 106; Ciołek 2001: 126ff, no. 198/128.

38 Bogucki, Jurkiewicz, Machajewski 2012: fig. 1; Zając 2017: 968.

39 Dymowski 2009: 16; Idem 2011: 166, no. 464 (Mw 87). several different finds. ${ }^{40}$ Due to the nature of these coin finds, i.e., the fact that they were minted under Trajan and Hadrian (with the exception of the Cappadocian drachma of Caracalla), but also that these are mostly drachmae equivalent to a denari$\mathrm{us}^{41}$ and, perhaps most of all, that they formed part (though in a rather small percentage) of hoards composed of $1^{\text {st }}$ - and $2^{\text {nd }}$-century denarii (found in both the Roman Empire and the Barbaricum), ${ }^{42}$ their arrival and distribution within the area of the Central-European Barbaricum could be connected with the inflow of silver Imperial coinage of the $1^{\text {st }}$, $2^{\text {nd }}$ (or possibly also the $3^{\text {rd }}$ ) centuries AD. ${ }^{43}$ This is not contradicted by the previously mentioned find of Trajan's drachma on the settlement site at Łęki Majątek (Kutno County) within a structure dated to the period ca. 260-280 AD. The authors of the publication concerning this particular find have taken note of the good condition of its preservation, precluding a long period of remaining in circulation and pointing rather to having been stored for a time in some sort of a safe-box (of a tribe or a clan), before it would be eventually deposited in the ground. ${ }^{44}$ From the perspective of archaeological cultures, the coin finds as described here have been attested with much consistency across the areas of the Przeworsk and Wielbark cultures. Moreover, the hoard of $1^{\text {st }}$ - and $2^{\text {nd }}$-century denarii from Lyshchytsa (Brest Voblasc'), which included a Lycian drachma of Trajan, should be associated with the latter culture. ${ }^{45}$

The inflow of provincial bronze and billon coins (as produced by the mint of Alexandria) should be considered within a different context. The best represented group among the finds of

40 The coins likely recorded in the hoards of Brzeziny, Wągrowiec County (Kunisz 1979: 79; Mitkowa-Szubert 1989: 41; Bogucki, Jurkiewicz, Machajewski 2012: 239) and Trzemeszno, Mogilno County (Kunisz 1973a: 117-118, no. 165; Bogucki, Jurkiewicz, Machajewski 2012: 239).

41 Cf. Krzyżanowska 1976: 15; Kunisz 1979: 65f; Zajac 2017: 968.

42 Cf. relevant lists in Kunisz 1979; Idem 1983; Bar 1985; Bodzek 2004; Bogucki, Jurkiewicz, Machajewski 2012: 239; Zając 2017: 968.

43 Cf. Lucchelli 1998: 130-163; Bursche 1996: 5865; Reece 2008; Dymowski, Myzgin 2014.

44 Cf. Bogucki, Jurkiewicz, Machajewski 2012: $239 f$.

45 Sidarovich 2014: 76, 86, no. 17, Pl. 3. 5. 
provincial bronze coinage reported from the present-day Lesser Poland is formed by pieces minted in the Balkan provinces. The number taken into account here refers to the amount of coin finds, not the number of pieces within them. ${ }^{46}$ This group comprises coins struck at Viminacium, of the COL VIM type, coins minted most likely at Apulum, of the Provincia Dacia type, ${ }^{47}$ as well as the municipal issues of Thrace and Macedonia.

Coins from the mint of Viminacium constitute by far a majority of finds reported for the area of Lesser Poland. This fact was already observed by Andrzej Kunisz, even though he had taken into consideration fewer coin finds at the time. ${ }^{48}$ To date, seven finds of this type have been recorded for the area we are concerned with (cf. Map 1). Three of them were known to A. Kunisz, ${ }^{49}$ namely a sestertius of Hostilian (251) found in the district Podgórze of Krakow (Kraków County) before the year 1824 (Pl. 1.5), ${ }^{50}$ a coin of the same denomination in the name of Trebonianus Gallus (251-253), found at Tarnów (Tarnów County) in 1964 (Pl. 1.7) ${ }^{51}$ and a sestertius of Philip the Arab (244-249) unearthed at Kraśnik Fabryczny (Kraśnik County) in 1954.52 Four more finds of sestertii have been reported

46 If we assume Andrzej Kunisz's hypothesis that the hoard from the vicinity of Chełm consisted entirely of Alexandrian coins to be correct, the volume of 1.5 litres, as specified in the WNA, should indicate the quantity of about 200 pieces; cf. Milutinović 2017: 186, note 21. Thus, the coins struck in Alexandria would be the largest group in terms of the number of pieces.

47 Găzdac 2011: 8; Găzdac-Alföldy, Găzdac 2008: 146; cf. Rakoczy 2018.

48 Kunisz 1973b: 36ff.

49 The recent publication by B. Borić-Brešković and M. Vojvoda on the circulation of Viminacium coins is not correct here as it takes note of only one find from southern Poland (2018: 86, Map 1).

50 Bandtkie 1824-1825 (previously, incorrectly attributed to S. Girtler); Piotrowicz 1928-1929: 53, no. 3; Gumowski 1958: 117, no. 12; Wielowiejski 1960: no. 607; Kunisz 1969: no. 103 III, Kunisz 1985: 93f, no. 111 III. 3; Kisza 1990: 113f, no. V.A.: 3, tab. IV; Kaczanowski, Margos 2002: 115, no. 349; Kolendo 2006: 256, no. 17 (coin designated here as AE2, following the publication by J. Eckhel, Doctrina Nummorum Veterum). The coin reportedly found "across the Vistula, outside Krakow."

51 Kunisz 1969: no. 256 IV; Idem 1970: 127-128; Idem 1985: 218, no. 277 IV (designated AE2).

52 Opozda 1970: 52; Bełkowska 1981: 148; Kunisz 1985: 104, no. 113 III. from Krakow (P1. 1.6) ${ }^{53}$ and Jakuszowice ${ }^{54}$ (coins of Trebonianus Gallus (251-253); Pl. 1.4) as well as from the environs of Tomaszów Lubelski (Tomaszów Lubelski County) (one coin in the name of emperor Trajan Decius (249-251) $)^{55}$ and Hrubieszów (Hrubieszów County) (with one in the name of Philip the Arab). ${ }^{56}$

Unlike the above pieces, we know of only one coin representing the Provincia Dacia type from the area under consideration, namely a sestertius struck in the year 246/7 in the name of Philip the Arab, which was found at Brzezie (Wieliczka County; P1. 1.2). ${ }^{57}$

Likewise, we know of just one coin from a Thracian municipal mint. This is a bronze piece in the name of Antoninus Pius (138-161) from Anchialos in Thrace, unearthed at the settlement site of the Przeworsk culture at Jakuszowice

53 As based on an inventory card from the early 1950 s made at the National Museum in Krakow, the unrecorded coin from a hoard found at Warszawska St. (Kunisz 1985: 96, no. 111/VIII). The composition of this hoard is not exactly known. According to some older literature, it consisted of debased antoniniani and some minor bronze coins of several $3^{\text {rd }}$ and $4^{\text {th }}$-century emperors, from Gallienus to Theodosius I (Jamka 1963: 191, 193; Kunisz 1985: 96). Although the hoard was deposited in the National Museum in Krakow, the turmoil of the Second World War and the ensuing mixing-up of many collections rendered any identification of individual pieces from this assemblage, among the broader numismatic collection, is very difficult or even impossible. The Viminacium sestertius of Trebonianus Gallus (inv. no. MNK-VII-A-4110; cf. SNG Kraków: 26, no. 49) has been likely ascribed to the hoard from Warszawska St. on the basis of a record found on the coin's ticket. All the other records on the hoard were lost during the war. It is noteworthy that the reconstruction of the information on the origins of the individual pieces of ancient coinage in the collection of the National Museum in Krakow was already performed in the years just after the Second World War by Dr M. Fredro-Boniecka, who served as the museum's custodian during the interwar period and in the first several years after the war. It is a matter of speculation to what extent Dr Fredro-Boniecka may have recalled the provenance of specific pieces from the collection after her five years' wartime absence in the museum.

54 Bursche 1997: 144, no. 104; Bursche, Kaczanowski, Rodzińska-Nowak 2000: 105, no. 104.

55 Dymowski 2008a: 56, B; Idem 2011: 224, no. 982 (Mp84).

56 Dymowski 2008a: 44, no. 2.

57 Martin 2.81.1; SNG Cop. 130; Pick 27 (identification: J. Bodzek); cf. Roczkalski, Włodarczak 2011: 367f, picture 13.2; Kaczanowski 2017: 49, no. 21.6. 9, tab. XXXVII: 24. 
(Kazimierz County; P1. 1.3). ${ }^{58}$ Unlike most of the other Roman coins found at Jakuszowice, this particular coin find is random, but its connection with this well-known site from the Roman period is obvious.

In the context of coins from the Balkan mints, we should also recall here one Macedonian coin (as mentioned by Aleksander Bursche and $\mathrm{M}$. Rudnicki) struck in the year $242 \mathrm{AD}$, found at Opatkowice (Proszowice County). ${ }^{59}$ The other Macedonian specimen from a find in the south of Poland is a bronze coin of Augustus (27 BC-14 AD), minted at Philippi. Found at Gródek (Hrubieszów County) and mentioned by Aleksander Bursche, it has never been thoroughly published. ${ }^{60}$

A majority of the coins from Viminacium mentioned above can be regarded as single finds, except for a piece found in Krakow which would have reputedly come from the hoard of Warszawska St. ${ }^{61}$ The coin found in the vicinity of Hrubieszów may have formed part of a hoard as well, but there is no definitive proof to support this view. ${ }^{62}$ In two instances, there are records referring to pieces from Viminacium as discovered alongside some other coins ${ }^{63}$ yet it is difficult to verify them.

A more significant fact is the discovery of a coin of Trebonianus Gallus (from the mint of Viminacium) during the regular archaeological excavation within the settlement of the Przeworsk culture at Jakuszowice. A similar significance can be attached to the above-mentioned sestertius of the Provincia Dacia type in the name of Philip the

58 AMNG II: 220, no. 414, tab. 6: 3; Varbanov 2002: 16, no. 42; Rudnicki 2014: 277f, no. 4, fig. 4.

59 Bursche 1999: 131; Bursche, Kaczanowski, Rodzińska-Nowak 2000: 119; Rudnicki 2014: 278.

60 Bursche 1999: 129. The coin was found in the field owned by Piotr Kania in 1998. Its identification and the authenticity of the find have been confirmed in a conversation with Prof. Aleksander Bursche. We would like to thank him for this item of information. The coin, which is now beyond our reach, has not been published in detail thus far.

${ }^{61}$ Cf. note 52.

62 Dymowski 2008a: 44.

63 Medium Imperial Aes in the name of Domitian and Trajan are mentioned along with the coin of Hostilian found in Krakow-Podgórze. It is still uncertain if those coins come from the same find; cf. Kunisz 1985: 94; Kisza 1990: 113f; Kolendo 2006: 256; the sestertius of Philip the Arab known from Kraśnik Fabryczny is reported to have been found along with a follis of Constantine the Great. However, as A. Kunisz notes (1985: 104, no. 113 III, note 1), these may have come from two different finds.
Arab, found in the course of the regular archaeological work at the settlement site from the Roman period at Brzezie. Both instances are validated by similar coins found to date.

It can be assumed that the finds of coins from Viminacium as reported from the territory of Lesser Poland are clustered in two broadly defined terrains. One of them can be identified in the region of the Upper Vistula basin, which is clearly related to the settlement area of the Przeworsk culture, ${ }^{64}$ whereas the other one is located in the north-eastern section of the territory, within the area occupied by the settlement of the Wielbark culture or around the boundary between the Wielbark and Przeworsk cultures. ${ }^{65}$ Such a distribution of the finds of Viminacium coins could be, at least to a certain extent, the result of the current state of research in this field, but it is also possible that it might reflect the actual directions of their movement (see further on).

At this point, let us add that the finds of coins from Viminacium, though much less common, have been reported also from the settlement areas of the Przeworsk and Wielbark cultures situated farther to the north. As regards the former culture, one should mention the environs of Radziejów (KuyavianPomeranian Voivodeship), where a coin minted at Viminacium in the name of an unspecified emperor may have been found in the year $2005,{ }^{66}$ while a bronze coin of Trebonianus Gallus produced in the year 252/253 comes from the area settled by the Wielbark culture, in this case from somewhere near Węgrów (Mazovian Voivodeship). ${ }^{67}$ Although it may be a reflection of the current state of research (it is notable that A. Kunisz did not know any finds of Viminacium coins from, as he would put it, "Central Poland"), it does seem that the territory of southern Poland, specifically Lesser Poland, would be exactly where the inflow of such coinage was more intense. Conversely, it was quite evidently less significant up north. Interestingly, we do not know of any relevant coin finds from Silesia, ${ }^{68}$ even though such finds have been reported for the adjoining regions to the east and south of Lesser Poland. From the area of the Chernyakhov

64 Specifically, the finds from Krakow-Podgórze, Warszawska St. in Krakow, Tarnów, and Jakuszowice.

65 E.g., the finds from Kraśnik Fabryczny, Hrubieszów, and Tomaszów Lubelski.

${ }^{66}$ Dymowski 2008b: 21; Idem 2011: 146, no. 306 (W52).

67 Dymowski 2008c: 87f; Romanowski 2008: 139, no. 232/1; Dymowski 2011: 182, no. 599.

68 Which could be possibly related to the current state of research as well. 
culture (i.e., generally speaking, from the territory of present-day Ukraine), we have records of at least 176 such coin finds, ${ }^{69}$ and of two more from the present-day state of Belarus. One bronze coin of Gordian III (238-244) was found a little farther north of the area settled by the Chernyakhov culture (Stary Krysk, Homyel' Voblasc'), ${ }^{70}$ while the other one, which is even more noteworthy, comes from an unidentified location in the Brest Voblasc', i.e., from the settlement area of the Wielbark culture. ${ }^{71}$ The latter one, a coin in the name of emperor Emilianus (year 253), is doubtful in the opinion of Vital Sidarovich, but considering its location as well as some other finds of Viminacium coins in the name of the same emperor as found within the area of the Chernyakhov culture, this seems to be an acceptable option. Farther to the north, in the area of West Baltic cultures milieu, three coins produced at Viminacium have been found. Two finds (coins in the name of Gordian III and Volusianus) were recovered with the use of metal detectors at Okunyov (Kaliningrad Oblast) in 2013, ${ }^{72}$ while at Machary (Mragowo County, Poland), a coin of Philip the Arab was found on the burial ground of the Bogaczewo culture located there (gravesite no. 209). ${ }^{73}$ Around 50 finds of coins from the colony of Viminacium have been recorded to the south

69 In general, according to the updated details, these pieces come from various finds: 40 coins of Gordian III, 67 of Philip the Arab, 22 of Trajan Decius, 21 of Trebonianus Gallus, 12 of Volusianus, 5 of Emilianus, 2 of Valerian, and 1 of Gallienus, all produced by the mint of Viminacium (Myzgin 2017: 26; Myzgin 2018: 92-93). For the most part, these are coins recovered as a result of detecting activity. The following coin finds have been published in detail: a coin of Philip the Arab found at Bratslav, Vinnytsia Oblast (Beidin 2012: 153, cat. 1), a coin of Trebonianus Gallus from Petrykovtsi (Beidin 2012: 153, cat. 4); of Trajan Decius from Koshevatoye (Kiev Oblast) (Beidin 2012: 154, cat. 11), a bronze coin of Trebonianus Gallus at Malopolovietskoye (Kiev Oblast) (Beidin 2012: 154, cat. 12), a bronze coin of Philip the Arab from the village of Staraya Ushnitsa (Khmelnytskyi Oblast) (Beidin 2012: 157, cat. 45), and a coin of the same emperor from Stryi (Lviv Oblast) (Piotrowicz 1936: 105, no. 95; Beidin 2012: 154, cat. 17). B. Borić-Brešković, M. Vojvoda (2018: 86, Map 1) follow the data from K. Myzgin and cite 170 coin finds from Ukraine, 2 from Belarus, and 1 from the area occupied by the milieu of the West Baltic cultures.

70 Sidarovich 2014: 76, cat. 14, P1. 2.8.

71 Ibidem: cat. 15, Pl. 2.3.

72 FRC PL database no. 17797, 17798.

73 Hollack, Peiser 1904: 21; identification:

A. Bursche. of the Polish section of the Carpathian range, in the territory of Slovakia. ${ }^{74}$ As it appears, these are

74 These coin finds are as follows: Hodejov, okres Rimavská Sobota - a medium bronze coin of Gordian III (Ondrouch 1964: 117, no. 343; Kaczanowski, Margos 2002: 396, no. 66); Kežmarok - a medium bronze coin of Philip the Arab (Kolnikova, Hunka 1994: no. 90; Kaczanowski, Margos 2002: 402, no. 95); Mojmírovce, okres Nitra - a bronze coin of Trajan Decius (Kolnikova, Hunka 1994: no. 91; Kaczanowski, Margos 2002: 414415, no. 157); Pláštovce, okres Levice - a sestertius of Gordian III (Ondrouch 1964: 117, no. 344; Kaczanowski, Margos 2002: 423, no. 194); Bratislava - a medium bronze coin of Gordian III (Ondrouch 1964: 116, no. 340), a three sestertii of Philip the Arab (Kolnikova, Hunka 1994: 75, no. 126; Stoklas 2017: 12, no. 3), two large bronzes of Philip the Arab (Budaj, Hunka 2018: 9697, no. 181, 183), a large bronze of Herennius Etruscus (Stoklas 2017: 12, n. 4); Dojč, okres Senica - a sestertius of Gordian III and as of Trebonianus Gallus (Stoklas 2017: 12, no. 6); Hurbanovo, okres Komárno - a sestertius of Trajan Decius and Hostilian, a sestertius and an as of Hostilian, an as of Trebonianus Gallus (Stoklas 2017: 12, no. 7; Budaj, Hunka 2018: 91, no. 170); Chotín, okres Komárno - a sestertius of Philip the Arab (Kolnikova, Hunka 1994: 85, no. 150), a medium bronze of Philip the Arab and Volusianus (Stoklas 2017: 12, no. 8), a bronze coin of Philip the Arab (Budaj, Hunka 2018: 85, no. 165); Komárno - a sestertius of Gordian III (Stoklas 2017: 13, no. 10; Budaj, Hunka 2018: 117, no. 266); Modrany, okres Komárno - a bronze of Philip the Arab (Stoklas 2017: 13, no. 12); Nitra - an as of Trebonianus Gallus (Budaj, Hunka 2018: 117, no. 269); Patince, okres Komárno - a small bronze of Gordian III (Stoklas 2017: 13, no. 15); Velky Meder, okres Dunajska Streda - a three sestertii and a large bronze of Gordian III, a sestertius of Trajan Decius and Volusianus (Stoklas 2017: 14, no. 20; Budaj, Hunka 2018: 105, no. 215); Záhorská Ves, okres Malacky - a sestertius of Philip the Arab (Stoklas 2017: 14, no. 21); Zohor, okres Malacky - a sestertius of Gordian III (Stoklas 2017: 14, no. 22; Budaj, Hunka 2018; 94, no. 178); Smolenice, okres Trnava - a medium bronze coin of Philip the Arab (Hlinka, Kolnikova, Kraskovska, Novak 1978: 27; no. 73); Iža, okres Komárno - a medium bronze coin of Philip the Arab (Hlinka, Kolnikova, Kraskovska, Novak 1978: 37-38; no. 114); Trenčianske Bohuslavice, okres Trenčín - a dupondius of Philip the Arab (Ondrouch 1964: 118, no. 350); Banská Štiavnica - a sestertius of Philip the Arab (Hlinka, Kolnikova, Kraskovska, Novak 1978: 33; Kaczanowski, Margos 2002: 383, no. 7); Bošacy, okres Trenčín - a dupondius of the same emperor (Ondrouch 1964: 118, no. 351) and finally Košuty, okres Galanta - a sestertius of Philip the Arab (Ondrouch 1964: 118, no. 352). More coins had been found in the hoards of Nové Zámky - a sestertius of Gordian III, a medium bronze coin of Herenius Etruscus, a medium bronze coin of Trebonianus Gallus (Ondrouch 1964: 149-150, no. 492), and Iža, okres Komárno - 
mostly single coin finds. In a study of the recent finds of Roman colonial coinage, B. Stoklas affirms that a vast majority of colonial coins represent the $3^{\text {rd }}$-century coinage of Viminacium. ${ }^{75}$ Unlike the territory of Poland, nevertheless, he points to the crucial role of economic factors such as near-border trading activity. ${ }^{76}$ In turn, from the historical lands of Bohemia and Moravia (the modern-day Czech Republic), we know of five coin finds of this type, mostly as part of hoards..$^{77}$ One of those coins was found within a settlement from the Roman period. Still, there are records of numerous finds from the territories farther south (present-day countries of Austria, Hungary, Slovenia, Croatia, Serbia, Romania, and Bulgaria), as listed by B. BorićBrešković and M. Vojvoda. ${ }^{78}$ From the eastern lands of Germany, we know of only one recorded find: a bronze coin in the name of Hostilian (251), found at Havelberg. ${ }^{79}$

Such a distribution of finds of coins from Viminacium in Poland and the neighbouring territories may suggest that they should have arrived in the present-day region of Lesser Poland from two different directions. Thus, the coins accumulated in the north-eastern part of the contemporary Lesser Poland, within the settlement area covered by the Wielbark culture, may have come in from the east as a result of the contact with the population of the Chernyakhov culture. Let us recall that both of these archaeological cultures are associated with Gothic

two medium bronze coins and one sestertius of Gordian III, one sestertius, one as, and one medium bronze coin of Philip the Arab, one sestertius of Trajan Decius, and one medium bronze coin of Trebonianus Gallus (Ondrouch 1964: 152-155, no. 497; Stoklas 2017: 15; Budaj, Hunka 2018: 88, no. 168). Recently, B. Stoklas has published another sestertius of Gordian III, found at Iža (okres Komárno) (Stoklas 2017: 9, no. 2). Differences in the nomenclature of particular denominations are due to the use of various names and designations by the authors referring to the earlier publications.

75 Stoklas 2017: 10.

76 Ibidem: 11.

77 These are as follows: 3 sestertii of Gordian III in the hoard of Nová Ves (Militky 2013: c. 151b/3-5); a sestertius of Philip the Arab in the hoard of Česká Lípa (c. 509/2); an unspecified bronze coin of the same emperor in the hoard of Vraný (c. 73/2), a sestertius of Trajan Decius found at Oskořinek (c. 293) and a coin of an unidentified ruler (sestertius) from the settlement of Zalužany dating from the Roman period (c. 363b/6).

78 Borić-Brešković, Vojvoda 2018: 86, Map 1. But let us notice that the map presented by the authors is not accurate in this respect.

79 Laser 1980: 159, no. VII. 06-1a. elements. A similar hypothesis could be applied to the coin finds from Węgrów (Węgrów County), farther up north, and the present-day Belarus (especially the one from the Brest Voblasc'). It is also possible that such coins may have reached the settlement area of the West Baltic cultures (the modern-day region of Mazuria and the Kaliningrad Oblast) through the contact with the people of the Chernyakhov culture. Such a direction of the inflow of the coins in question is apparently confirmed by the map of the finds of the Viminacium coinage included in the article by B. Borić-Bresković and M. Vojvoda ${ }^{80}$ Unfortunately, both the map and the text of the article leave out a certain part of the finds localized to the north of the Carpathians, thus distorting the view of the movement of Viminacium coins into the territory of Lesser Poland, in particular as regards the previously mentioned finds from the river basin of the Upper Vistula. Although in this case as well, the possibility of the inflow of such coins from the east cannot be ruled out, we believe it is plausible that they might have arrived from the southern (present-day Slovakia) or south-western (Bohemia and Moravia) directions. This may have been possible in consideration of the above relevant pieces as recorded in Slovakia (with a bronze coin of Gordian III found at Hadejov being the closest to Poland) and the Czech Republic.

The chronological structure of the coins from Viminacium as found in Lesser Poland falls within the years 244-253 AD. At the same time, certain differences which may be, to some extent, the outcome of a coincidence arising from a limited number of discoveries can be discerned between the "Wielbark" and "Upper-Vistula" clusters of finds. In the former one, the records include coins of Philip the Arab (2) and Trajan Decius (1), but including the area more to the north of Lesser Poland, also bronze pieces of Trebonianus Gallus (1) and Emilianus (1). A slightly different structure is characteristic of the finds coming from the Upper Vistula region, with a prevailing share of coins in the name of Trebonianus Gallus (3), complemented with a random bronze coin of Hostilian. Compared with the finds reported from Ukraine, Slovakia, and the Czech Republic (Bohemia and Moravia), the finds from the territory of Poland are marked by the absence of coins minted in the reign of Gordian III (238-244). It is also worth noting here that the mint of Viminacium began to operate in October $239,{ }^{81}$ and continued its activity with

80 Borić-Brešković, Vojvoda 2018: 88, Map 1.

81 Dušanić 1976: 58. 
some interruptions only up to the year $254-255 .^{82}$ The production of coins by this establishment is related directly to the decline in minting activity during this particular period and the filling in for the shortage of bronze currency in the Balkan provinces (hence the particularly wide range of circulation). ${ }^{83}$

Unlike the above, coin finds of the Provincia Dacia type are very uncommon among the numismatic discoveries over the territories of the Centraland Eastern-European Barbaricum. ${ }^{84}$ In Poland, we have not recorded coin finds of this type, except for the above-mentioned find from Brzezie (in Lesser Poland). Likewise, they have not been reported from Slovakia and the Czech Republic. In the area of the Chernyakhov culture, a coin find of this type is known from Pervomaysk (Nikolayev Oblast), where a coin in the name of Philip the Arab was found, ${ }^{85}$ and Nizhniy Bishkin (Kharkiv Oblast) - a bronze coin of Hostilian. ${ }^{86}$ These coins must have come in directly from the south. Also, the last-mentioned finds from Ukraine and the coin found at Brzezie point to the movement of the Provincia Dacia type into Central and Eastern Europe and should attest to the fact that their particular status is rather due to what we know from the current state of our research. On the other hand, the inflow might not have been very intense on account of the production-related factors and the nature of the circulation of such coinage. ${ }^{87}$

It is difficult to think of reasons other than the current state of the research to explain the presence of just one coin from a Thracian mint reported for the region of Lesser Poland as well as the total absence of pieces from the municipalities of Lower Moesia, ${ }^{88}$ especially as relatively numerous finds of such coins have been known from both central and northern Poland (but these are mostly from the period of the Severan dynasty) ${ }^{89}$ Such coins have also been

\section{Borić-Brešković, Vojvoda 2018: 74.}

83 Ibidem: 86.

84 A. Kunisz (1973b: 37) and A. Bursche (1984: 241) do not know of any such coin finds from the area of the Central- and Eastern-European Barbaricum.

${ }_{85}$ Beidin 2012: 155, no. 18.

86 Ibidem: 155, no. 27.

87 Cf. Kunisz 1973b: 37; Găzdac 2008: 275277; Găzdac-Alföldy, Găzdac 2005: 651-653; Găzdac, Alföldy-Găzdac 2008: 139-146; cf. Rakoczy 2015: 55ff.

${ }_{88}$ This is in contrast to the coin finds from some other regions of the Central- and Eastern-European Barbaricum.

89 Environs of Warsaw - Caracalla?, Thracian or Moesian mint, Nikopolis? (Romanowski 2008: 138, no. 228/1; Dymowski 2011: 181, no. 591 (Mw 133)); Mokracz, Bełchatów commune - a bronze coin of reported from the territories adjacent to Poland such as the present-day countries of Belarus, ${ }^{90}$ Ukraine, ${ }^{91}$

Caracalla struck at Serdica (Kubiak 1978: 209, no. 66); Sulejów - a bronze coin minted at Marcianopolis in the name of Caracalla (Kubiak 1978: 210, no. 71); Nawiady, Piecki commune - a bronze coin of Caracalla struck at Serdica, found along with a bronze piece of Severus Alexander from the mint of Rome (Kubiak 1978: 209, no. 67); Wawrochy, Szczytno commune - a bronze coin of Heliogabalus struck at Marcianopolis, found during the excavations (Kubiak 1978: 210, no. 72); Gdańsk - a bronze medallion of Caracalla struck at Peryntos (Ciołek 2001: 58, no. 77/5).

90 Adamenka, Mahiloŭ Voblasc' - a bronze coin of Geta struck at Augusta Traiana (Sidarovich 2014: 75, cat. 6); Horval', Homyel' Voblasc' - a bronze coin of Gordian III struck at Hadrianopolis (Sidarovich 2014: 75, cat. 8, Pl. 2.1); raion Mazyr, Homyel' Voblasc' - a bronze coin of Gordian III and Tranquilina struck at Anchialos (Sidarovich 2014: 75f, cat. 11, P1. 2.2); Buiaki, Brest Voblasc' - a coin of the same emperor minted at Deultum (Sidarovich 2014: 76, cat. 7, Pl. 2.3); Haradzets, Brest Voblasc' - also a bronze coin of Gordian III struck at Deultum (Sidarovich 2014: 75, cat. 9, Pl. 2.4); Rubashki (formerly Brody), Vitebsk Voblasc' - a bronze coin of Philip II struck at Tomis (Sidarovich 2014: 85, cat. 10).

91 Krutogorb, Vinnytsia Oblast - a bronze coin of Gordian III and Tranquilina struck at Marcianopolis (Beidin 2012: 153, cat. 3); Rayki, Zhitomir Oblast a bronze medallion of Heliogabalus struck at Philippopolis (Beidin 2012: 153, cat. 5); Krylos, Ivano-Frankivsk Oblast - a bronze coin of Philip the Arab from Marcianopolis (Beidin 2012: 154, cat. 7); Chernin, Kiev Oblast - a bronze coin of Heliogabalus struck at Marcianopolis (Beidin 2012: 154, cat. 14); Peresopnica, Rivne Oblast - a bronze coin of Septimius Severus from Marcianopolis (Beidin 2012: 155, cat. 21); Rovienski Uyezd, Rivne Oblast - a bronze coin of Macrinus from Marcianopolis (Beidin 2012: 155, cat. 22); Gardnikovtsi, Ternopil' Oblast - a bronze coin of Gordian III from an unidentified mint in Thrace (Beidin 2012: 155, cat. 24); Kotsiubinchyki, Ternopil' Oblast - a bronze coin of Gordian III from an unidentified mint in Thrace (Beidin 2012: 153, cat. 26); Bronikovka, Khmelnytskyi Oblast - a bronze coin of Gordian III struck at Marcianopolis (Beidin 2012: 157, cat. 38); Malevtsi, Khmelnytskyi Oblast - a bronze coin of Caracalla struck at Philippopolis and a bronze coin of Gordian III struck at Nikopolis ad Istrum (Beidin 2012: 157, cat. 40 and 42); Satanov, Khmelnytskyi Oblast - a bronze coin of Gordian III and Tranquilina struck at Anchialos (Beidin 2012: 157, cat. 44); Yurkov$\mathrm{ka}$, Cherkasy Oblast - a bronze coin of the same emperor struck at Hadrianopolis (Beidin 2012: 157, cat 50). Furthermore, as based on the current analysis of the finds from Ukraine, there are records of 88 coins minted at Marcianopolis, mainly in the reigns of Caracalla, Elagabalus, Severus Alexander, Macrinus, and Gordian III; 35 coins struck at Nikopolis ad Istrum, 25 - at Tomis, 
and the Czech Republic. ${ }^{92}$ Of particular note here is the great number of finds related to the area of the Chernyakhov culture. To date, the bronze coin of Antoninus Pius found at Jakuszowice has been something of an exception in the south of Poland. Incidentally, although minted in the $2^{\text {nd }}$ century $\mathrm{AD}$, this particular piece may have been brought into the settlement of Jakuszowice much later, sometime during the $3^{\text {rd }}$ century.

On the other hand, the single coins of Macedonia as reported from Opatkowice (Kraków County) and Gródek (Sokołów County) should fit in with the picture of very rare finds of this type from the regions of central and northern Poland as well as from the neighbouring countries. Apart from the above pieces, we know of only one coin find of this kind in Poland: a bronze coin in the name of Caracalla (197-217), most likely from Dion, found at Łęcze (Elbląg County). ${ }^{93}$ Similar single finds of Macedonian coins have been recorded in Belarus ${ }^{94}$ and the Czech Republic. ${ }^{95}$ Overall, we have the information on 50 coins from Macedonian mints as found over the area of the Chernyakhov culture. ${ }^{96}$

8 - at Istrios, mostly under the Severan dynasty and Gordian III; 19 - at Odessos and 6 - at Dionysopolis, mainly in the reign of Gordian III; 82 coins struck at Deultum under Severus Alexander, Gordian III and Philip the Arab; 35 coins minted at Anchialos mainly under Maximinus Thrax and Gordian III; 32 coins struck at Hadrianopolis mainly during the reigns of Caracalla and Gordian III; 19 coins of Serdica, mostly from Caracalla's reign; 17 coins of Mesembria, mainly from the reigns of Gordian III and Philip the Arab; 16 coins struck at Augusta Traiana and 13 coins from Pautalia, struck under Caracalla; 9 coins struck at Bizye; 7 - at Philippopolis and 3 - at Byzantium (Myzgin 2017: 26; Idem 2018: 90).

92 These coins may have likely been part of some larger assemblages (hoards): Neznašov - a bronze coin of Gordian III struck at Dionysopolis (Militky 2013: c. 690/1); Nespeky - a bronze coin of Antoninus Pius from Philippopolis (Militky 2013: c. 40/1); Starý Kolín - a bronze coin of Commodus from Philippopolis (Militky 2013: c. 178/13).

93 Bogucki et al. 2006.

94 Raion Krupki, Minsk Voblasc' - a bronze coin of Philip the Arab minted at Thessalonica (Sidarovich 2014: 86, cat. 16. Pl. 2.10). Vital Sidarovich considers this coin find to be uncertain.

95 Horineves - a bronze coin of Caracalla struck at Stobi (Militky 2013: c. 431/1).

96 Malevtsi, Khmelnitskyi Oblast - a dupondius of Caracalla struck at Edessa (Beidin 2012: 157, cat. 41). To date, coins from the following mints have been recorded: 10 - struck at Thessalonica, mainly in the reign of Severus Alexander; 5 - at Pella; 4 - at Edessa; 3 - at Stobi; 3 - at Amphipolis; 1 from Dium as well as 23 pseudo-autonomous pieces issued most likely during the reign
The absence of $3^{\text {rd }}$-century Thracian, Moesian, and Macedonian coins in Lesser Poland may indicate a different direction (other than from the south) of inflow for such coinage. In fact, they may have reached the regions of central Poland and Pomerania from the south-east, from the settlement area of the Chernyakhov culture, or from the south-west, i.e., from the territory of the modern-day Czech Republic.

Many years ago, Aleksander Bursche contested the commercial causes of the inflow of Thracian and Lower-Moesian coins into the territories of the Barbaricum, pointing to the political nature of this phenomenon, ${ }^{97}$ especially such factors as the relation between the movement of such coinage and the Gothic Wars (256-270 AD) as well as the service of Germanic (Gothic) detachments in the Roman army. ${ }^{98}$ In consequence, coins from Lower Moesia, Thrace, the colony of Viminacium and the Provincia Dacia, and possibly from Macedonia, may have been brought into the territorial space of the Barbaricum as a result of such relations. As for the present-day region of Lesser Poland, another significant factor may have been the redistribution of such coinage within the bounds of the Barbarian world specifically as a consequence of the relations/ contact among the populations of the Chernyakhov, Wielbark, and Przeworsk cultures, or possibly between the population living across the territories to the north of the Carpathians and those who inhabited the lands to the south of this mountain range. The character of those relations remains an open question, but the participation of organized military groups/bands of warriors from the Wielbark and/ or Przeworsk cultures in incursions into the Roman Empire is a very likely field of activity.

South-east is also the direction of inflow with which we should associate the Lesser Poland finds of coins minted in the names of the rulers of the Bosporan Kingdom between the $1^{\text {st }}$ century BC and the $3^{\text {rd }}$ century AD as well as coins produced in Olbia in the early centuries AD. Bosporan coins have been known from several finds reported from the region of the historically defined Lesser Poland. Since an analysis of this type of coin finds is given elsewhere, in the present text we have included only a summary of the most important conclusions. ${ }^{99}$

of Gordian III (Myzgin 2017: 26; Idem 2018: 90).

97 Bursche 1984: 241f; Idem 1996: 118.

98 For the relation between the inflow of Roman provincial coinage and the Gothic Wars, cf. also, e.g., Brajčevskij 1959: 54; Myzgin 2011: 323; Magomedov 2006: 47; Beidin et al. 2006: 126; Beidin 2012: 150.

99 Cf. Bodzek, Madyda-Legutko 2013; Idem 2018. 
Four such coins have been found in Lesser Poland, all of them representing bronze issues and recorded either in the settlement area of the Przeworsk culture or in the Polish Carpathians. Generally speaking, they had been struck between the turn of the $1^{\text {st }}$ century $\mathrm{BC}$ and the $1^{\text {st }}$ century $\mathrm{AD}$ and the first half of the $3^{\text {rd }}$ century AD. The earliest dated coin represents the issue with the monogram $\mathrm{BAE}$, allegedly found at Nowy Sącz-Zabełcze (Nowy Sącz County; P1. 1.10). ${ }^{100}$ Another coin, struck in the name of Cotys I (45/46-67/8), was found at Zarzecze (Przeworsk County; Pl. 1.12), ${ }^{101}$ while one coin of Rescuporis II (68/9-93) was reported to have been part of a hoard from Gorlice-Glinik Mariampolski (Gorlice County, Pl. 1.8), ${ }^{102}$ which also contained an autonomous coin minted at Olbia in the $2^{\text {nd }}$ century AD (P1. 1.9). Finally, a coin in the name of Rescuporis III (211/2-228/9) was reportedly found at Staniątki (Niepołomice County, P1. 1.11). ${ }^{103}$ As a matter of fact, all those coins had been discovered prior to the year 1958: in two cases, it was already during the second half of the $19^{\text {th }}$ century and in one, before the Second World War. The lack of any factual information on the circumstances and the character of each specific find have an impact on appraising the credibility of some of them. Moreover, it is somewhat surprising that there have been no new coin finds of this type from the region of Lesser Poland reported in recent years. On the other hand, some new discoveries of Bosporan coins reported for central Poland validate the movement of coinage of this type into the territory of present-day Poland. The case in point are the coins found at

100 Gumowski 1958: 117, no. 30; Madyda-Legutko 1995: 118, no. 469; Idem 1996: 47; Bodzek, Madyda-Legutko 2013: 69; Idem 2018. The circumstances of the finding of this coin are unknown, which bears on the credibility of this coin find.

101 Piotrowicz 1936; Bodzek, Madyda-Legutko 1999: 142-143; Idem 2013: 69; Idem 2018.

102 Skowronek 1973; Kubiak 1978: 195, no. 9; Madyda-Legutko 1995: 11, no. 177; Idem 1996: 47; Bodzek, Madyda-Legutko 2013: 69; Idem 2018. From the hoard of originally about 200 pieces, only 4 coins have survived. According to the first publication of this deposit, with no photographs of the coins, all of the four surviving pieces were minted in the Bosporan Kingdom and at Olbia. Nevertheless, the subsequent verification of the assigned designations led to the changes in the attribution of two coins, effectively as having been struck at Korykos in Cilicia and at Knossos on the island of Crete, respectively. This is not without a significant impact on the reliability of the numismatic find in question.

103 Piotrowicz 1936: 104; Kubiak 1978: 201, no. 34.
Skłóty (Kutno County) ${ }^{104}$ and Gąski (Inowrocław County). ${ }^{105} \mathrm{~A}$ great number of coins in the names of the rulers of the Bosporan Kingdom have been found and reported from the settlement area of the Chernyakhov culture, ${ }^{106}$ but few from the territory of modern-day Belarus. ${ }^{107}$ This would point to the eastern or south-eastern direction of the inflow of the coins under consideration, as a result of the interaction between the peoples that inhabited the territories of the modern-day countries of Ukraine and Poland in Antiquity. Differences in the numbers of the relevant finds would indicate that the lands of today's Poland were rather on a margin of the main channels of inflow for the coinage of this type. The disproportion appears to be even larger in view of an unprecedented surge in coin finds recorded in Ukraine as caused by the increased activity of detectorists. ${ }^{108}$ Not many finds of Bosporan coins are known from the territory of Dacia, which perhaps may not allow us to rule out the possibility of at least some partial south-eastern

104 The so-called double denarius of Inintimaos (234/5-238/9); cf. Bodzek, Madyda-Legutko 2013; Idem 2018 .

105 A bronze coin of an unidentified Bosporan ruler from the $2^{\text {nd }}$ century AD; cf. Idem.

106 In 2012, K. Myzgin and G. Beidin took note of 44 such finds reported for the territory of Ukraine (Myzgin, Beidin 2012: 63-73, cat. 1-44). As for other relevant pieces, let us mention two staters of Rescuporis $\mathrm{V}$ (242/3-276/7) found on a site from the Roman period at Komariv, Chernivtsi Oblast (Myzgin 2013) and a hoard from a locality called Ksizovo (Beidin, Myzgin 2015). The finds from Komariv are particularly significant in that they have been unearthed at a site of the Chernyakhov culture during the regular archaeological excavations. It should be stressed that the amount of finds of Bosporan coins in Ukraine and Russia has been growing. In G. Beidin's more recent works, there are references to as many as 85 coin finds (2017) and to 519 pieces of Bosporan coinage found to date (2018: 13).

107 Minsk - an electron stater of Sauromates II (173/174-210/211) (Sidarovich 2014: 83, cat. 2; Myzgin, Beidin 2012: 75, no. 57) and a bronze coin of Rescuporis IV (242/243-276/277) (Sidarovich 2014: 84, cat. 3; Myzgin, Beidin 2012: 75, no. 58); Maladzyechna, Minsk Voblasc' - a bronze coin of Rescuporis V (242/243276/277) (Sidarovich 2014: 84, cat. 4; Myzgin, Beidin 2012: 75, no. 59); Rusilaŭka-Navasiolki, Hrodna Voblasc' - a bronze coin of Mithridates III (39/40-45/46) (Sidarovich 2014: 84, cat. 5; Myzgin, Beidin 2012: 75, no. 60).

108 We have details of new coin finds found there especially from scholars such as Dr Kiryll Myzgin, who has recorded many new discoveries on the basis of information obtained from detectorists. 
direction of inflow. ${ }^{109}$ It should be noted that very few finds of Bosporan coins minted during the early centuries $\mathrm{AD}$ have also been reported from Germany, ${ }^{110}$ but it does not affect the general conclusions on the direction of their inflow movement. Another noteworthy fact is that among Polish finds of Bosporan coinage there are no pieces struck later than the 230s AD, with most of the coins found dating from the $1^{\text {st }}-2^{\text {nd }}$ centuries $A D$. This would suggest that some of them might have arrived well before the Gothic Wars or possibly during that period (256-270 AD). ${ }^{111}$ Should we assume the hoard of Gorlice-Glinik Mariampolski to be authentic, it is possible to recognize that the Bosporan coins arrived in the regions of southern Poland from the south-eastern direction along with coins of Olbia produced in the course of the $1^{\text {st }}-2^{\text {nd }}$ centuries $A D$ and perhaps at least some lesser quantities of coins struck by the mints of Asia Minor and Greece. ${ }^{12}$ But let us note that one find of an Olbian coin dating from the $1^{\text {st }}$ century AD has also been reported from Moravia (location: Brno-Slatina), which may suggest the movement of such coins into the regions north of the Carpathian range from the south. ${ }^{113}$

Coins produced by the mints in the northern regions of Asia Minor are not commonly found in the present-day Lesser Poland. All we know are

109 A bronze coin of Sauromates I (93/94-122/123) was found at Horia, Tulcea County (Mitrea 1964: 380, no. 52; Kunisz 1992: 158) and another bronze piece of Aspurgos at Poiana, Galaţi County (Mitrea 1978: 366, no. 63, fig. 2. 2-3); cf. Bodzek, Madyda-Legutko 2018: 78. The last-mentioned coin is of particular significance as it was found and recorded during regular archaeological works.

110 Referring to the following finds from Germany: Wiebelskirchen - AE of Sauromates I and Totorses - FMRD, Abt. 3, Saarland: 123, 1080/ 1-2; Gross-Gerau - a bronze coin of Sauromates I - FMRD, Abt. 5, Bd 3, Hessen, Darmstadt; Kirchberg - coins of Totorses, Rescuporis VI as well as coins dating from the period from the $1^{\text {st }}$ century $\mathrm{BC}$ to the $3^{\text {rd }}$ century AD - FMRD, Abt. 5, Bd 3, Hessen, Kassel: 37f, nos. 3011/7 and 9; 67, no. $3038,1-2$

111 K. Myzgin and G. Beidin (2012: 60f) have classified the finds of Bosporan coins from Ukraine into the following three chronological: 1. Coins minted before the period of the Gothic Wars; 2. Coins minted and in circulation during the Gothic Wars; 3. Coins minted after the period of the Gothic Wars. Finds from Poland can be associated with the first two groups.

112 Cf. Bodzek, Madyda-Legutko 2018.

113 On this coin find, see Militký 2004; Bodzek, Madyda-Legutko 2018: 73. just two finds of such coins, one of them found by archaeologists and the other one being possibly a randomly found piece. The former coin, a large bronze coin of Caracalla struck at Caesarea in Cappadocia, was found during the archaeological work on the site of the settlement of the Przeworsk culture at Jakuszowice (Pl. 1.15). ${ }^{114}$ Unfortunately, this coin find has no specific archaeological context as it comes from surface layers as a result of prospecting with the use of a metal detector. The other one, a small autonomous bronze piece from Temnos in Aeolia, datable broadly to the period 117-268 AD, was unearthed as a random find at Zabrodzie (Żarnowiec commune, Zawiercie County; Pl. 1.16). ${ }^{115}$

Basically, both of those coins should be linked with the settling activity of the Przeworsk culture. In this context, the coin find of Jakuszowice, reported during the process of regular archaeological works from the area settled in the Roman period, is of particular importance. Several finds of pieces produced by the mints of the northern provinces of Asia Minor have been known from Silesia, but also from central and northern Poland. For instance, a Nicomedian bronze piece in the name of Severus Alexander found near Jastrzębie-Zdrój in Silesia should be associated with the Przeworsk culture. ${ }^{116}$ The settlement area of the same culture is also where a bronze coin issued in Hadrian's reign by the Bithynian Koinon has been found (Kozłubów, Uniejów commune). ${ }^{117}$ In turn, a bronze coin of Gordian III from Nikaia was found at Kołoząb (Płońsk County) in the right-bank part of Mazovia, which was settled by the population of the Wielbark culture in the early centuries of the first millennium AD. This piece was recovered from the necropolis dating from the Roman period. ${ }^{118}$ Finally, a large bronze coin in the name of Severus Alexander minted at Prusias in Bithynia was unearthed at Kiejkuty Stare (Szczytno County). ${ }^{119}$ The latter find could be associated with the milieu of the West Baltic cultures. To the list of coins produced by the mints of northern Asia Minor, we could also add a coin of

114 Bursche 1997: 143, no. 98, tab. VIII; Bursche, Kaczanowski, Rodzińska-Nowak 2000: 105, tab. I, no. 74

115 Cf. SNG Cop. 274; SNG v. Aulock 1677.

116 This piece was initially misidentified as a bronze coin of Alexandria (Łonak 2005: 92, no. 112C; Bursche 2007: 211; Ciołek 2008: 88, no. 132).

117 Dymowski 2011: 156, no. 377 (Mw47).

118 Paszkiewicz 2000: 26; Romanowski 2008: 50, no. $78 / 1$.

119 Kubiak 1978: 208, no. 63. 
Caracalla struck at Midaeum in Phrygia, which was found at Dąbie near Krosno Odrzańskie (Krosno County), i.e., within the area of the Luboszyce culture $^{120}$ and a pseudo-autonomous bronze piece of Hephaestia in Lemnos, an island situated off the north-western coast of Asia Minor, reported from Bąbolin (Inowrocław County). ${ }^{121}$ This latter piece is of particular note due to the fact that it was found in the area of Gąski-Wierzbiczany-Bąbolin, which is known for its richness in numismatic finds, including provincial coinage. The previously mentioned Bosporan coin find comes from the locality of Gąski as well.

Besides, a coin from the southern part of Asia Minor was found in Lesser Poland as well, but the authenticity of the discovery of an autonomous bronze piece struck at Korykos in Cilicia, which would have reputedly come from the hoard of Glinik Mariampolski (now a part of Gorlice; Pl. 1.14), should raise some questions and the information about it should be treated with much reservation. ${ }^{122}$ Finds of coins from the southern provinces of Asia Minor are also known from Silesia and central Poland. Allegedly, a coin from an unspecified mint in Pisidia was found near the Lower-Silesian town of Nowa Ruda (Kłodzko County). ${ }^{123}$ In the region of Kuyavia, one small pseudo-autonomous coin from Apollonis in Lydia was unearthed in a field in 2015 (Janocin, Inowrocław County). Overall, more than 40 other Roman coins have been found there. ${ }^{124}$ Finds of coins minted at Antioch in Pisidia were reported from the following two places: Łódź a bronze coin of Philip the Arab found during construction works before the year 1952, ${ }^{125}$ and Kuty (Węgorzewo County) - a bronze coin in the name of Gallienus unearthed during ploughing work. ${ }^{126}$ The former can be linked to the settlement of the

120 Dymowski, Jellonek 2017: 246.

121 Dymowski, Więcek 2018: 169.

122 Bodzek, Madyda-Legutko 2018.

123 Cf. Łonak 2005: 148, no. 202.1. The coin was reported to have come from a hoard of bronze pieces. W. Łonak makes no reference to any mint, only quoting (apparently, in extenso) a description from the records of acquisitions of the Münzkabinett in Berlin. Yet it should be noted that the hoard was of an uncertain provenance, with bronze coins of Syracuse, Pisidia, Alexandria, but also some antoniniani and bronze pieces from the $4^{\text {th }}$ century in its composition. Most probably, this assemblage of coins should be considered as a collection brought over to Poland in modern times (cf. Bursche 2007: 212).

124 Dymowski, Więcek 2018: 176-177.

125 Gupieniec 1954: 44; Kubiak 1979: 58; Bursche 1996: 197; Kaczanowski, Margos 2002: 135.

126 Antoniewicz 1955: 358-360.
Przeworsk culture, while the latter - with the West Baltic culture milieu.

A comparatively high number of coins and medallions minted in Asia Minor have also been recorded throughout the settlement area of the Chernyakhov culture, in the territory of the present-day Ukraine, ${ }^{127}$ whereas just one coin from the mint of Parium has been found and reported

127 These are as follows: a bronze coin of Gordian III from Tium, found at Belayevka, Odessa Oblast (Myzgin 2012: 197, no. 1); a bronze coin of Caracalla from Cessarium, found at Poniatovka, Odessa Oblast (Myzgin 2012: 197, no. 2); a bronze coin of Macrinus from Sinope, found near the village of Dumanov, Khmelnytskyi Oblast (Myzgin 2012: 197, no. 3; Beidin 2012: 157, no. 39); a bronze coin of Gallienus struck at Ephesus, found near the village of Shymkovtsi, Khmielnytskyi Oblast (Myzgin 2012: 197, no. 4); a bronze coin of Gordian III struck at Nikaia, found at Malievtsi, Khmelnytskyi Oblast (Beidin 2012: 157, cat. 43); a bronze coin of Gordian III minted at Trebizond, found near the village of Khrushchovaya Nikitovka, Kharkiv Oblast (Myzgin 2012: 197, no. 6); a bronze coin of Saloninus struck at Amisos, found at Pavlovo, Kharkiv Oblast (Beidin 2012: 156, cat. 28); a bronze coin of Heliogabalus struck at Trebizond, found at Starye Valki (Beidin 2012: 156, cat. 30); a bronze coin of Caracalla from Sinope, found at Taranovka, Kharkiv Oblast (Beidin 2012: 156, cat. 31); a bronze coin of Julia Domna and a coin of in the name of an unidentified emperor struck at Trebizond, found at Khvorostovo, Kharkiv Oblast (Beidin 2012: 156, cat. 32-33); a bronze coin of Gordian III struck at Trebizond, found at Khrushchevaya Nikitovka, Kharkiv Oblast (Beidin 2012: 156, cat. 34); a bronze coin of Severus Alexander minted at Caesarea in Cappadocia, found at Yavtuchovka, Kharkiv Oblast (Beidin 2012: 156, cat. 36); a bronze coin of Gordian III struck at Trebizond, found at Zinkov, Poltava Oblast (Beidin 2012: 155, cat. 19); a bronze coin of Gallienus struck at Ephesus, found at Shymkovtsi, Ternopil' Oblast (Beidin 2012: 157, cat. 46); a bronze coin of Lucius Verrus minted in Asia Minor, found at Smila, Cherkasy Oblast (Beidin 2012: 157, cat. 49). Among other finds, let us mention four bronze medallions struck in the cities of Asia Minor. A medallion of Hadrian struck at Ephesus, found in Vinnytsia or Zhytomyr Oblast (Myzgin 2015: 106, cat. 1, pl. 1, fig. 1). The other ones were minted at Pergamon: a medallion of Septimius Severus found at Lomachintsi, Chernivtsi Oblast (Myzgin 2015: 106, cat. 2, pl. 1, fig. 2) and two medallions of Caracalla found somewhere between the villages of Borshevtsi and Mogyliv-Podil'skyi, Vinnytsia Oblast (Myzgin 2015: 107, cat. 3, pl. 1, fig. 3), and Kurovechka, Khmelnytskyi Oblast (Myzgin 2015: 107, cat. 3, pl. 2, fig. 4); a hoard of Kiev found in the year 1876 may have contained 44 coins struck at Antioch in Pisidia, but this item of information is uncertain (Kunisz 1973b: 33). 
from Belarus (Bautsichy, Hrodna Voblasc'). ${ }^{128}$ The hoard found at Starý Kolín (Czech Rep.) consisted of Imperial and provincial coins of Thrace alongside some bronze pieces of Severus Alexander struck at Nikaia ${ }^{129}$ and in the name of Gordian III from Cius. ${ }^{130}$ In the territory of Slovakia, a bronze coin of Commodus minted at Prusa ad Olympum has been reported from Podunajské Biskupice (a municipal district of Bratislava). ${ }^{131}$ For the most part, bronze coins from the mints of Asia Minor as recorded to date come from the western and southern parts of the peninsula, while there are no finds coming from the north-eastern section of Asia Minor. Nonetheless, a large number of coins from those regions have been reported for the area to the east of the Dnepr. Similarities among the coins dating from the $2^{\text {nd }}$ and $3^{\text {rd }}$ centuries as found in Lesser Poland and over the area west of the Dnepr would suggest similar forms of contact with the Roman Empire. ${ }^{132}$

It appears that a majority of coins produced by the mints of the provinces of Asia Minor have reached the space of Central-European Barbaricum, including the present-day Lesser Poland, as a result of political relations between the Barbarian people(s) and the Imperium Romanum. This should concern the coins struck by the mints located in the northern part of Asia Minor as well as those from other regions of the peninsula. At least some of them became Barbarian property in connection with the Gothic raids on Asia Minor after the year 250 AD. ${ }^{133}$ Still, it ought to be noted that some pieces may have arrived in the territories of Central- and EasternEuropean Barbaricum through Moesia and Thrace, rather than directly from the provinces of Asia Minor. Numerous finds attesting to the presence in Moesia of coins produced in the Bithynian city of Nicaea come from such localities as Pecine, the necropolis of Viminacium. ${ }^{134}$ Hence, such coins may have come into Poland through Ukraine or directly from the south, through Slovakia or the historical lands of Bohemia (modern-day Czech Republic).

Very limited and partly uncertain group among the finds reported from the present-day Lesser Poland is formed by coins minted in the Levant, Syria, and Mesopotamia. In the first place, we should mention a bronze coin struck in

128 Sidarovich 2014: 86, no. 18.

129 Militky 2013: 158, no. 178/17.

130 Ibidem: no. 178/18.

131 Kolnikova, Hunka 1994: 63, no. 79.

132 Cf. Myzgin 2018: 93-95.

133 Salamon 1971: 128; Kunisz 1973b: 32; Myzgin

2018: 97; Dymowski, Więcek 2018: 169.

134 Vojvoda 2017. the $1^{\text {st }}$ or $2^{\text {nd }}$ century $\mathrm{AD}$ at Ascalon found at Zarzecze (Pl. 1.17). ${ }^{135}$ According to the archival records, the coin was found on 2 August 1882, yet it would remain to be unidentified for a long time. ${ }^{136}$ There have basically been no comparable coin finds from Lesser Poland. The coins of Heliogabalus from Tyr (found at Wąchock (Starachowice County)) and Nero from Caesarea in Palestine (reported from Nowa Stupia (Kielce County)) are considered to be uncertain. ${ }^{137}$ From the regions of central and western Poland, we know of several more coins produced in the East. In the 1960s, a bronze piece of Severus Alexander, struck at Nisibis, was found during surveying works performed near Żuromin (Żuromin County). ${ }^{138}$ Coins of Antioch in Syria, in the names of Antoninus Pius, Severus Alexander, and Trebonianus Gallus, have been found in central Poland, at Krzyż Wielkopolski (Czarnków-Trzcianka County), ${ }^{139}$ in Łódź, ${ }^{140}$ as well as in Silesia, during construction work at Jasienica Górna (Nysa County). ${ }^{141}$ Coins produced in the [Near] East are not found frequently in the neighbouring countries, either. It is only from western Ukraine that we know of a coin in the name of Tiberius struck at Antioch on the Orontes, found at Zherebki Korol (Ternopil' Oblast). ${ }^{142}$

It is worth observing here that the previously mentioned coin of Ascalon from the locality of Zarzecze was reportedly found along with a bronze coin of Cotys I, the ruler of the Cimmerian Bosporus. ${ }^{143}$ But whether the two coins had been found together or simply acquired on the same day remains an open question. ${ }^{144}$ If those pieces had been found together, this might have pointed to the south-eastern direction of their movement from the area of the Chernyakhov culture, but a very small amount of finds of coins produced in the Levant and farther east and the scarcity of data

135 Piotrowicz 1936: 107; Kubiak 1978: 205, no. 49; Bodzek, Madyda-Legutko 1999.

136 Cf. Bodzek, Madyda-Legutko 1999: 142f.

137 Wąchock: Kunisz 1985: no. 296; Nowa Słupia: Kunisz 1985: no. 163.

138 Romanowski 2008: no. 268/1.

139 Dymowski 2011: 117, no. 54; Ciołek 2007: 115, no. 173 , coin 2 .

140 Gupieniec 1954: 44; Kubiak 1979: 58; Bursche

1996: 197; Kaczanowski, Margos 2002: 135.

141 RPC IX 1851; Bartkowiak 2006: 97.

142 Piotrowicz 1932/1933: 124, no. 4.

143 Piotrowicz 1936: 107 - according to this publication, the Bosporan coin was struck at Pergamon.

144 The authors of the present text would favour the hypothesis that those pieces were acquired on the same day, not found together. 
on the circumstances of such finds do not make the task of interpreting them any easier. Those coins must have arrived in the space of the CentralEuropean Barbaricum most likely as a consequence of political relations. Coins minted at Antioch seem to be of particular importance here, due to the status of the city as one of the key political centres and a rallying place for the Roman legions operating in the East. They may have been brought into present-day Poland by soldiers of Germanic origin or obtained by members of Germanic tribes from soldiers of other ethnic origin who would return to Europe.

Finally, the last group from among the provincial coins found in Lesser Poland is formed by pieces produced by the mint of Alexandria. To date, only two such finds have been reported: a hoard from the environs of Chelm (Chełm County) ${ }^{145}$ and a single find from somewhere around Włodawa (Włodawa County). ${ }^{146}$ The hoard of Chełm, all inside a container of 1.5 litre (holding about 200 pieces), was presumably composed entirely of coins of Alexandrian provenance. ${ }^{147}$ It has been possible to identify only several billon tetradrachms, coined in the $3^{\text {rd }}$ century AD in the names of Probus (276-282), Carus (282-283), Numerian (282-284), Diocletian (284-305), and Maximian (285-305). ${ }^{148}$ In turn, a billon tetradrachm dating from the year 288-289 $\mathrm{AD}$, struck in the name of Maximian Herculeus, was found near Włodawa. ${ }^{149}$ There is no doubt that the same chronological span could be ascribed to a hoard of 21 Alexandrian tetradrachms struck between the years 278 and $295 \mathrm{AD}$, found in the vicinity of Turets, Hrodna Voblasc' in Belarus, ${ }^{150}$ and to another Belorussian find of a single tetradrachm

145 Kunisz 1973a: 20, no. 14; Kubiak 1978: 208, no. 61; Kunisz 1985: 36, no. 25 II; Bursche 1996: 160, no. 94; Kaczanowski, Margos 2002: 25-26, no. 77; Janco 2002: 30, no. 5; Bodzek 2007: 80-82; Milutinović 2017: 170.

146 Gurba 1958: 47; Kunisz 1969: 156, no. 286; Kokowski 1984: 49, no. 96; Kunisz 1985: 246, no. 308; Bursche 1996: 160, no. 93; Kaczanowski, Margos 2002: 346, no. 849; Janco 2002: 30, no. 4; Milutinović 2017: 170 .

147 Cf. Kunisz 1973b: 31; Idem 1985: 36, no. 25, 2; Milutinović 2017: 186.

148 Three tetradrachms of Numerian, Diocletian, and Maximian: Kunisz 1973a: 20, no. 14; Idem 1985: 36, no. 25 II; seven coins minted in the names of Probus, Carus, Diocletian, and Maximian: Bodzek 2007: 80-81.

149 Kunisz 1969: 156, no. 286; Kokowski 1984: 49, no. 96; Kunisz 1985: 246, no. 308; Kaczanowski, Margos 2002: 346, no. 849 .

150 Sidarovich 2013; Idem 2014: 87, cat. 20. of Aurelian (270-275), found at Veraskova, Hrodna Voblasc'. ${ }^{151}$ It seems that these coin finds should be associated with the settlement area of the Wielbark culture. Coins of Alexandrian origin have been reported from the territory of the Chernyakhov culture, ${ }^{152}$ but also in the Czech Republic (historical lands of Bohemia and Moravia) ${ }^{153}$ and Slovakia. ${ }^{154}$

151 Ibidem: no. 19.

152 A coin of Gallienus from Chernihiv (Janco 2002: 30, no. 1); a coin of the same emperor for Salonina, found at Lado Kecchoveli (Beidin 2012: 154, cat. 9; Janco 2002: 30, no. 2); a coin of Claudius Gothicus from an unspecified location (Beidin 2012: 155, cat. 23); a coin in the name of Maximian Herculeus from Zuravka (Beidin 2012: 157, cat. 47; Janco 2002: 30, no. 3).

153 Coins of Nero have been found at Bosonohy and Znojmo (Janco 2002: 28, no. 1-2 (Moravia); the hoard of Strážný included a tetradrachm of Hadrian (Militky 2013: c. 724/6); a drachma of the same emperor was found at Svitavy (Militky 2013: c. 419/1; Janco 2002: 28, no. 7 (Moravia); Alexandrian coins in the name of Hadrian found at Mušov and Uherský Brod as well (Janco 2002: 28, no. 3, 10 (Moravia); tetradrachms of Gallienus reported from Petrovice (Militky 2013: c. 511; Janco 2002: 28, no. 1 (Bohemia) and Morkůvky (Janco 2002: 28, no. 4 (Moravia); a tetradrachm of Probus found at Radim (Militky 2013: c.171/3; Janco 2002: 28, no. 4 (Bohemia); a coin of the same ruler found at Černilov (Militky 2013: c. 428; Janco 2002: 28, no. 5 (Bohemia); a tetradrachm of Claudius Gothicus found as part of one possible deposit reported from Vyšehořovice (Militky 2013: c. 341/1; Janco 2002: 28, no. 2 (Bohemia), along with a tetradrachm of Aurelian for Severina (Militky 2013: c. 341/2; Janco 2002: 28, no. 3 (Bohemia); a tetradrachm of Claudius Gothicus also reported from Vícemilice (Janco 2002: 28, no. 5 (Moravia); a tetradrachm of Aurelian found at Letovice (Janco 2002: 28, no. 6 (Moravia); a tetradrachm of Carinus reported from the environs of Slaný (Militky 2013: c. 68; Janco 2002: 28 , no. 6 (Bohemia); tetradrachms of Diocletian found as part of a votive deposit from Starý Kolín (Militky 2013: c. 119/18; Janco 2002: 28, no. 10 (Bohemia), in hoards of Markvartice (Militky 2013: c. 473/1), and Bitov (Janco 2002: 28, no. 9 (Moravia), and in one possible deposit of Dolánky (Militky 2013: c. 588/1); a tetradrachm of Maximian Herculeus found in each of the hoards: Kolín (Militky 2013: c. 107/3-4, c. 179a/5; Janco 2002: 28, no. 12 (Bohemia), a most probably votive deposit from Teplice (Militky 2013: c. 640/C7; Janco 2002: 28, no. 8 (Bohemia), and Valtrovice (Janco 2002: 28, no. 8 (Moravia); tetradrachms of Philip the Arab, Tacitus, Probus, Maximian Herculeus found at Polná (Janco 2002: 28, no. 7 (Bohemia); tetradrachms of Aurelian for Severina, and in the names of Tacitus, Probus, Carinus, Maximian Herculeus, and Diocletian, reported from Mostecko (Janco 2002: 28, no. 9 (Bohemia); Kunisz 1973b: 32).

154 A tetradrachm of Claudius Gothicus found at Pavlice (Janco 2002: 28, no. 1 (Slovakia). 
Likewise, Alexandrian coins have most likely formed part of several hoards and single finds reported from the regions of western and central Poland. In Silesia, these are especially the hoards found at Sobótka (Wrocław County) ${ }^{155}$ and Zielona Góra (Zielona Góra County). ${ }^{156}$ Among single finds, let us mention a bronze coin in the name of Hadrian (117-138), found at Gorzupia Dolna (Żagań County), ${ }^{157}$ a tetradrachm of Trajan (98117) - Nowa Cerekwia, (Glubczyce County), ${ }^{158}$ and a tetradrachm of Diocletian - Głogów (Głogów County). ${ }^{159}$ For central Poland, Alexandrian coins have been known from the finds from Nekla (Września County), ${ }^{160}$ and Krotoszyn (Krotoszyn County). ${ }^{161}$ The former one (Nekla) consisted of several coins, including a tetradrachm of Nero, while in the last-mentioned case (Krotoszyn), it was a tetradrachm of Diocletian struck between the years 288 and 289 AD. Other relevant records include single finds of tetradrachms in the name of Claudius II Gothicus from Rywałd (Grudziądz County) ${ }^{162}$ and Nakło (Nakło County), ${ }^{163}$ whereas another tetradrachm, in the name of Philip I the Arab, was found at Szczytno (Szczytno County). ${ }^{164}$ An uncertain specimen is a $3^{\text {rd }}$-century coin from Skarszewy (Starogard Gdański County). ${ }^{165}$ If finds of Alexandrian coins reported from Silesia, Greater Poland, and Kuyavia could be tied with the population of the Przeworsk culture, the ones that we know from Pomerania and Warmia are more likely associated with the elements of the Wielbark culture.

The prevailing denomination among the recorded finds of coins produced in Alexandria is the billon tetradrachm of the $3^{\text {rd }}$ century, which achieved a fairly wide circulation across Europe. Frequently, such coins would form part of hoards also known from

155 Ciołek 2008: 231, no. 342; Milutinović 2017: 172, no. 92 .

156 Kunisz 1973a: 136-137, no. 196; Bursche 1996: 170, no. 72; Janco 2002: 30, no. 9; Milutinović 2017: 172, no. 95 .

157 Bolin 1926a: 83, no. 110; Wielowiejski 1960: 314, no. 353B; Konik 1965: 54; Janco 2002: 30, no. 1; Ciołek 2008: 75, no. 107.

158 Bolin 1926a: 78, no. 61h; Ciołek 2008: 166169, no. 252/8.

159 Konik 1965: 51, no. IV; Bursche 1996: 188, no. 35; Ciołek 2008: 68, no. 90.

160 Kubiak 1978: 209, no. 68; Janco 2002: 30, no. 7.

161 Kubiak 1978: 209, no. 64.

162 Ciołek 2007: no. 248A.

163 Gałęzowska 2016: 239, no. 44.

164 Bolin 1926a: 233, no. 152.

165 Janco 2002: 30, no. 3; Ciołek 2007: no. 257/4. the modern-day countries of France, Switzerland, Belgium, Great Britain, and Germany. ${ }^{166}$ Coins of Alexandria may have functioned locally as a sort of auxiliary currency, especially at a time when debased antoniniani had remained in circulation. ${ }^{167}$ There are several hypotheses that have attempted to explain the inflow of Alexandrian coinage into the Barbaricum. Due to the amount of pieces found and the finds themselves, it is quite difficult to agree on one all-encompassing hypothesis. A. Kunisz indicated that the movement of Alexandrian coins into the area of the Chernyakhov culture and northern Europe from the regions on the Black Sea coast. It is presumed that the distribution of Alexandrian coins may have been related to the decline of many provincial mints and, consequently, the complementing of local demand for the currency in circulation. ${ }^{168}$ A. Bursche has pointed to the inflow of Alexandrian coins from the Danubian regions, situated along or close to the limes, which would move along with the troops, and eventually arriving in the territories of the Barbaricum. Besides, tetradrachms may have been used as a portion of the remuneration paid out to the auxiliaries, where soldiers of Barbarian origin were allowed to serve. This hypothesis would be confirmed by the greater monetary deposits brought directly from Egypt, for instance, as a result of the conflict with Achileus (297-298 AD). ${ }^{169}$ As M. Janco argues, Alexandrian coins would presumably come from northern Africa together with various kinds of goods, such as terra sigillata, as a consequence of the decline in the number of mints in Europe. ${ }^{170}$ According to B. Magomedov, the inflow of tetradrachms along with some other coin denominations from the East, which had reached the area of the Chernyakhov culture, can be attributed to the spoils from the participation in the Gothic Wars (256-270 AD). He also observes that the Gepids may have served in the Roman forces as well, thus taking part in military campaigns in the East towards the late $3^{\text {rd }}$ century AD. ${ }^{171}$ In turn, L. Vakulenko holds the opinion that the finds of bronze coinage from the late $3^{\text {rd }}$ century, as well as of provincial coins in general, would testify to the development of trade relations. ${ }^{172}$ On the basis of the currently conducted research on the finds of provincial

166 Cf. Kunisz 1973b: 32, 34; Janco 2002: 29;

Milutinović 2017: 164, 168, 171.

167 Kunisz 1973b: 34.

168 Kunisz 1973b: 34-35.

169 Bursche 1996: 16, 128; Idem 2006: 222.

170 Janco 2002: 18, 25.

171 Magomedov 2008: 173-174.

172 Vakulenko 2010: 182. 
coinage, D. Milutinović connects the presence of Alexandrian coins with the existence of trade routes and long-distance commerce. ${ }^{173}$ It is likely that the finds from Lesser Poland, just as those from the adjacent regions, should be linked with the arrival in the Barbaricum of Alexandrian coinage as well as issues of antoniniani and the early follises from the late $3^{\text {rd }}$ century, specifically with remunerations paid out to the Goths for their service under Roman command. ${ }^{174}$

Apart from all the above groups of provincial coinage of definite provenance, coin finds in Poland also include some individual pieces minted in other regions of the Roman world. A notable example is a bronze coin in the name of the archon Kydas struck at Knossos in Crete during the $1^{\text {st }}$ century BC, which is presumed to have been a part of the previously mentioned hoard of Gorlice-Glinik Mariampolski (P1. 1.13). Interpretations of how this particular piece may have appeared there is strictly connected with a comprehensive analysis of this deposit of an uncertain credibility. Yet if we assume that the hoard under consideration is an authentic find, it should be recognized that the plausible provenance is the south-eastern direction, along with the inflow of Bosporan coinage.

The finds of Roman coins as recorded in Poland also include some amount of indeterminate coins bearing Greek inscriptions. Unfortunately, what we do have at our disposal is largely the information as given in numismatic literature, without any possibility of verification. As regards Lesser Poland, we know of one coin in the name of (probably) Marcus Aurelius with a Greek legend, found at Nowosiółki (Chełm County). ${ }^{175}$ In central and northern Poland, such finds are represented by the hoards of Brzeźno (Człuchów County) $)^{176}$ and some location in the proximity of the Drwęca river (Brodnica County). ${ }^{177}$ The hoard from Brzeźno was unearthed during ploughing work sometime before the year 1834, but there is no information on exactly where and how the coins of the Drwęca river hoard were found as well as what happened to the contents of the both hoards.

A coin of Caracalla bearing the Greek legend ANTSEINEINO $\Sigma$ was recovered from the grave no. 202 located on the burial ground of the Bogaczewo

173 Milutinović 2017: 164-166, 173.

174 Bursche, Czarnecka 2006: 217-218.

175 Nosek 1957: 304; Wielowiejski 1960: no. 894; Kunisz 1985: 151, no. 164; Kaczanowski, Margos 2002. 222 .

176 Ciołek 2007: 23, no. 19.

177 Ibidem: 43-44, no. 53. culture near Muntowo (Mragowo County). ${ }^{178}$ Some of the finds, such as the provincial coins from the settlement complex Gąski-Wierzbiczany-Bąbolin (Inowrocław County) have never been published in full. It is known that apart from the already mentioned two coins of the Bosporan Kingdom and Lemnos, some other provincial pieces had been found there. In view of the absence of any specific data on the attribution of the coin finds in question, they cannot be examined in terms of the direction, character, and chronology of their inflow.

Provincial coins form only a small portion of all the finds of Roman coinage in Lesser Poland. In total, 33 pieces representing this type of issues have been recorded, of which a third (10 finds/ coins) have been reported over the course of the last thirty years. Among the more recent finds, there are also some pieces produced by the previously unattested places. Two coins come from the mints in Macedonia (pieces reported from Gródek and Opatkowice), while one Aeolian coin from Temnos (found at Zabrodzie). Several coins were recovered during regular archaeological works, most notably the first coin of the Provincia Dacia-type ever found in Lesser Poland (location: Brzezie) and a large bronze coin from Caesarea in Cappadocia (Jakuszowice). To these, we should also add probably four recent finds of coins from the colonial mint of Viminacium (Hrubieszów, Jakuszowice, environs of Tomaszów Lubelski). The provincial coin found at Zarzecze many years ago have been re-identified, whereas newly formulated conclusions on the finds such as the hoard of Gorlice-Glinik Mariampolski and the one from the environs of Chełm have broadened the geographical range of the provincial coins or their timeline.

The arrival of silver pieces struck in the provinces should be associated with the same political, and to a certain degree also economical, factors which determined the wave of silver Imperial coinage coming into the territories of the Barbaricum. Among the denarii found in Poland to date, the greatest number are those produced between the reigns of the emperors Trajan and Marcus Aurelius. Should we conjecture that the coins would have been deposited in the ground following around 40 years after having been issued, the main wave of inflows would fall on the period 160-210 AD. ${ }^{179}$ However, we cannot ignore the fact that scholars give very different dates for the beginning of that

178 Bolin 1926b: 236, no. 185.

179 Dymowski 2013: 95. 
wave. ${ }^{180}$ According to A. Bursche and M. Erdrich, the intense inflows of Roman coinage would start in particular with the outbreak of the Marcomannic Wars (169-180), ${ }^{181}$ but some other scholars argue for dating this phenomenon to earlier periods: $\mathrm{T}$. Lucchelli suggesting a time between the reigns of Trajan (98-117) and Antoninus Pius (138-161), ${ }^{182}$ and R. Wolters opting for the reign of Antoninus Pius or Marcus Aurelius (161-180). ${ }^{183}$

A. Dymowski has distinguished at least four stages of the inflows of Roman coins. The first wave of Roman denarii would have come in the later years of Trajan's reign, in connection with the Dacian wars (101-106 AD), and the next one towards the end of Hadrian's reign (117-138) or in the early years of Antoninus Pius' reign. Another phase would begin in the final years of the latter emperor's reign or under Marcus Aurelius and, subsequently, with the advent of Septimius Severus' reign (193-211). ${ }^{184}$ On the other hand, L. Lind suggests the decades of $240 \mathrm{~s}$ and $260 \mathrm{~s} \mathrm{AD}$ as the periods of the inflows of denarii. ${ }^{185}$ Some of those coins might have, of course, appeared alongside $3^{\text {rd }}$-century denarii or antoniniani. ${ }^{186}$ The inflow period coinciding with the years ca. 160-210 $\mathrm{AD}$ would correspond to the provincial drachmae reported from Lesser Poland, of which five were minted in the emperor Trajan's reign and one under Hadrian. The drachmae of eastern provenance continued to be kept in circulation along with the volumes of silver coinage of the Roman Empire before they would end up in hoards. ${ }^{187}$

Pieces dating from the $3^{\text {rd }}$-century make up the greatest proportion among the provincial bronze coins found in the territory of the present-day Lesser Poland. At least 15 out of 33 coin finds are those minted in the $3^{\text {rd }}$ century AD. These are mostly coins produced by the mints of Alexandria and Viminacium. The other group is formed by coins of the $2^{\text {nd }}$ century (two pieces). The remaining coins were struck in the $1^{\text {st }}$ century $\mathrm{BC}$ and the $1^{\text {st }}$ century $\mathrm{AD}$, or are still indeterminate (the bronze piece from Temnos found at Zabrodzie (Wyszków County) has a dating range of 117-268 AD).

180 Bodzek 2018: 191-192.

181 Bursche 1994: 472; Idem 2006: 222; Erdrich

2001: 127.

182 Lucchelli 1998: 160.

183 Wolters 1999: 385.

184 Dymowski 2013: 111.

185 Lind 1988: 205.

186 Bursche 2004: 201; Dymowski 2013: 114.

187 Bodzek 2004: 150.
It is probable that many $3^{\text {rd }}$-century coins may have reached the space of the Barbaricum under consideration chiefly as a consequence of political relations. In the first place, the connection with the Gothic Wars should be mentioned here (256-270 AD). Plundering raids of the Goths and some other Barbarian tribes on the provinces of the Balkan peninsula and Asia Minor resulted in large amounts of spoils, including coins (but also probably personnel and equipment seized away from mints) being brought over to the territories settled by the Barbarians. ${ }^{188}$ This is particularly evident in the form of very numerous coins struck by the mints of the Balkans and Asia Minor as found across the settlement area of the Chernyakhov culture. ${ }^{189}$ Some amounts of coins arrived in the Barbaricum as a result of the service of Germanic (e.g., Gothic) units in the Roman military and their participation in the Roman Empire's campaigns, especially in the East. Likewise, we should not rule out the hypothesis of redistributions of certain portions of coinage through the Barbarian world, e.g., among the tribes in alliance or groups of warriors. The coins produced in Dacia, Thrace, Moesia (Viminacium), and Bithynia may have likely arrived predominantly during the second and third quarters of the $3^{\text {rd }}$ century AD. ${ }^{190}$ Also, at least some of the provincial coins of the $1^{\text {st }}-2^{\text {nd }}$ centuries $\mathrm{AD}$ would have most probably been brought over into the Barbaricum along with pieces of the $3^{\text {rd }}$-century issues. Among the finds reported from Lesser Poland, it is worth paying special attention to the unusually well-represented pieces produced by the mint of Viminacium, which was operational only over the course of a little more than a decade (239-253/54) with the main objective to make up for the shortage of bronze coinage in the Balkan provinces. ${ }^{191}$ It is no surprise then that those coins, on account of such factors as the distance, multiple issues, and the chronological coincidence of production, had found their way into the historical region of Lesser Poland and some other territories of the Barbaricum (especially the modern-day Ukraine) as a result of the Barbarian raids. The other significant group is composed of billon tetradrachms of Alexandria. In this case, the number of finds is perhaps lower, but these consist of many pieces. The coins represent a different

188 Bursche, Myzgin 2017: 249-250, Dymowski, Więcek 2018: 169-170.

189 Myzgin 2017; Idem 2018: 87-97.

190 Kunisz 1973: 27, 31, 37; Myzgin 2018: 97.

191 Borić-Brešković, Vojvoda, 2018: 74. 
chronological scope as they must have arrived primarily towards the late $3^{\text {rd }}$ and in the early $4^{\text {th }}$ century ${ }^{192}$ from the regions along the Danube, not far from the limes of the Roman Empire, brought over with the troops and then spreading into the expanse of the Barbaricum. ${ }^{193}$ In this case as well, the circumstances of the inflow are related to aspects of political relations, especially Germanic units' service in the Roman forces. ${ }^{194}$

It is also noteworthy that regardless of the time of their arrival, the provincial coins may have remained in use across the territories of the Barbaricum for much longer, as attested by such finds as the previously mentioned hoard from Warszawska St.in Krakow that contained coins up to and including the reign of Theodosius I (379-395). ${ }^{195}$

Bronze coins constitute a major part among the finds of provincial coinage in the Barbaricum. Nevertheless, they would comprise only a very small percentage $(1.28 \%)$ among the general volume of bronze coinage reaching the territory of Central-European Barbaricum up to the mid- $3^{\text {rd }}$ century $\mathrm{AD}(8.83 \%$, among the finds). But we should also recall, on the other hand, that apart from the areas occupied by the settlement of the West Baltic cultures, shares of bronze pieces among the finds of Roman coins are relatively low across the space of the Central-European Barbaricum. ${ }^{196}$ Due to their character, the value of bronze coins could not equal that of silver or gold coins, hence their inflow could not have been so intense in the $1^{\text {st }}$ and $2^{\text {nd }}$ centuries, or in the early $3^{\text {rd }}$ century, as it had been in the case of silver coinage. It is also notable that some of the Roman bronze currency coming into the Barbaricum was used as raw material and is thus impossible to grasp in the body of the coins being found. ${ }^{197}$ The metallographic examination and comparative analyses performed by A. Bezzenberger have shown similarities among materials used for the making of jewellery and elements of clothing, but also the alloy used for bronze coinage. ${ }^{198}$ Some of the coins were used as pendants, as may be inferred from the apertures in

192 Kunisz 1973b: 35.

193 Bursche 1996: 128; Idem 2006: 222.

194 Bursche 1996: 16, 128; Idem 2006: 222.

195 Cf. Kunisz 1985: 96.

196 Kunisz 1973b: 30; Zapolska 2008: 179-180; Idem 2011: 1116; Idem 2013: 105-108.

197 Bursche 2008: 400-401, 406-407; Zapolska 2014: 82-83.

198 Bezzenberger 1904; Zapolska 2014: 82-83. a sestertius of Lucius Verus from Borowa ${ }^{199}$ and a sestertius of Commodus from the gravesite no. 88 of the burial ground near Bolshoe Isakovo. ${ }^{200}$ In the milieu of the West Baltic cultures, bronze coins would be used frequently as funerary donatives. Brass sestertii with their shiny surfaces, imagery, size, and their general resemblance to gold were perceived as attractive among the inhabitants of the northern Barbaricum, especially in the context of the amber trail. ${ }^{201}$ It seems that provincial coins served the same purposes as Imperial bronze coinage in the Barbaricum. ${ }^{202}$ Compared with the sestertii, however, not all of the provincial bronze coins resembled those struck in gold. Provincial coins were issued in bronze, copper, or brass, with possible greater or smaller admixtures of lead. Unfortunately, it is sometimes impossible to determine the material of a given coin with accuracy because of its condition of preservation or availability. Moreover, we do not possess a great number of details of relevant examination results. ${ }^{203}$ As a result, provincial bronze pieces were used as raw material, tokens of prestige, funerary gifts, or possibly (e.g., in the area of the Chernyakhov culture) also for the purposes of local trading transactions. ${ }^{204}$

\footnotetext{
199 Wagner, Zając 2018.

200 Zapolska 2014: 82.

201 Bursche 2008: 400-401, 406-407; Zapolska
} 2009: 1117, 1123; Idem 2014: 80-82.

202 At Machary, a coin of Philip the Arab from Viminacium was found on the burial ground of the Bogaczewo culture (Hollack, Peiser 1904: 21); at Muntowo, a bronze coin of Caracalla (Bolin 1926b: 236, no. 185); at Norusai in Lithuania, a coin from Nikaia; a bronze coin of Gordianus III from Marcianopolis, used probably as a pendant, found at Kozhlin in Volhynia (Kunisz 1973b: 37).

203 Amandry, Burnett et al. 1992: XVII; Cowell, Craddock, Pike, Burnett 2000. Depending on a period and region, brass coins (in a golden hue) were issued at some locations in Bithynia and Pontus, Asia, Cilicia, and Achaea (Amandry, Burnett et al. 2015: 817, 829). A completely different question are coins struck in orichalcum, issued by the mint of Rome for Antioch, Cyrenaica, Cappadocia, and Cyprus (Amandry, Burnett et al. 2015: 815, 826; Carradice, Cowell 1987: 27-30). On the basis of the research on the provincial coins from the period of the Flavian dynasty, it can be said that coins made of orichalcum were much more often issued in the northern part of Asia Minor, while bronze coins prevailed in the south (Cowell, Craddock, Pike, Burnett 2000: 673-674).

204 Myzgin 2018: 97. 
Finally, one more aspect should be mentioned here. Some of the finds of provincial coinage can be linked with important political centres within the territory of the Barbarian world. For the region of Lesser Poland, we should first make a mention of the settlement of the Przeworsk culture at Jakuszowice. ${ }^{205}$ It is often cited, quite correctly, as an example of particularly considerable presence (as for Poland) of Roman coins found. To date, a total number of 116 pieces have been found. Among them, there are five bronze coins, of which three come from the provincial mints of Caesarea in Cappadocia, Anchialos, and Viminacium. ${ }^{206}$ As we have noted, the settlement at Jakuszowice must have most likely served as an important political centre, which could be somehow confirmed by the diverse provenance of the provincial coins found there. On the other hand, the presence of the above-mentioned pieces within the area of such a politically significant centre would also somehow corroborate, though indirectly, the political nature of the inflow of Roman provincial coins into the Barbaricum. A similarly varied character is reflected by the partially still unpublished finds of provincial coinage from the area of the previously mentioned complex of settlements in the commune of Gniewkowo (Kuyavia).

205 Bursche, Kaczanowski, Rodzińska-Nowak 2000.

206 Bursche, Kaczanowski, Rodzińska-Nowak 2000; Rudnicki 2014. 
Tab. 1. Silver Roman Provincial Coins in Lesser Poland

\begin{tabular}{|l|l|l|l|l|l|l|l|l|l|}
\hline No. & Findspot & $\begin{array}{l}\text { Type } \\
\text { of coin find }\end{array}$ & $\begin{array}{l}\text { Mint / } \\
\text { Province }\end{array}$ & Issuer & Dates & $\begin{array}{l}\text { Denomi- } \\
\text { nation }\end{array}$ & Remarks & References & Collection \\
\hline $\mathbf{1}$ & $\begin{array}{l}\text { Nietulisko Małe, } \\
\text { Ostrowiec District }\end{array}$ & $\begin{array}{l}\text { Hoard } \\
\text { Nietulisko } \\
\text { Małe II }\end{array}$ & Amisos & $\begin{array}{l}\text { Hadrian } \\
(117-138)\end{array}$ & $\begin{array}{l}132-133 / \\
133-134 \mathrm{AD}\end{array}$ & $\begin{array}{l}\text { AR, } \\
\text { Drachm }\end{array}$ & $\begin{array}{l}\text { Found between } \\
1942-1943\end{array}$ & $\begin{array}{l}\text { Babelon, } \\
\text { Reinach } 83\end{array}$ & $\begin{array}{l}\text { The Archae- } \\
\text { ological and } \\
\text { Ethnograph- } \\
\text { ical Museum } \\
\text { in Łódź }\end{array}$ \\
\hline $\mathbf{2}$ & $\begin{array}{l}\text { Nietulisko Małe, } \\
\text { Ostrowiec District }\end{array}$ & $\begin{array}{l}\text { Noard } \\
\text { Nietulisko }\end{array}$ & $\begin{array}{l}\text { Caesarea, } \\
\text { Cappadocia }\end{array}$ & $\begin{array}{l}\text { Trajan } \\
(98-117)\end{array}$ & $\begin{array}{l}113 / 114- \\
114 / 115 \mathrm{AD}\end{array}$ & $\begin{array}{l}\text { AR, } \\
\text { Drachm }\end{array}$ & $\begin{array}{l}\text { Found in 1939. } \\
\text { Accidental find }\end{array}$ & $\begin{array}{l}\text { Sydenham } \\
216 ; \\
\text { Metcalf 69a }\end{array}$ & $\begin{array}{l}\text { Institute of } \\
\text { Archaeology, } \\
\text { Jagiellonian } \\
\text { University }\end{array}$ \\
\hline $\mathbf{3}$ & $\begin{array}{l}\text { Wojków, Mielec } \\
\text { District }\end{array}$ & Hoard & Lycia & $\begin{array}{l}\text { Trajan } \\
(98-117)\end{array}$ & 98-99 AD & $\begin{array}{l}\text { AR, } \\
\text { Drachm }\end{array}$ & Found in 1885 & BMC 9-11 & unknown \\
\hline $\mathbf{4}$ & $\begin{array}{l}\text { Wojków, Mielec } \\
\text { District }\end{array}$ & Hoard & Lycia & $\begin{array}{l}\text { Trajan } \\
(98-117)\end{array}$ & $98-99$ AD & $\begin{array}{l}\text { AR, } \\
\text { Drachm }\end{array}$ & Found in 1885 & BMC 9-11 & unknown \\
\hline $\mathbf{5}$ & $\begin{array}{l}\text { Żulice, Tomaszów } \\
\text { Lubelski District }\end{array}$ & Hoard & Lycia & $\begin{array}{l}\text { Trajan } \\
(98-117)\end{array}$ & $98-99$ AD & $\begin{array}{l}\text { AR, } \\
\text { Drachm }\end{array}$ & Found after 1970 & $\begin{array}{l}\text { BMC 9; } \\
\text { SNG Cop. 45 }\end{array}$ & $\begin{array}{l}\text { Museum in } \\
\text { Zamość }\end{array}$ \\
\hline $\mathbf{6}$ & $\begin{array}{l}\text { Żulice, Tomaszów } \\
\text { Lubelski District }\end{array}$ & Hoard & Lycia & $\begin{array}{l}\text { Trajan } \\
(98-117)\end{array}$ & 98-99 AD & $\begin{array}{l}\text { AR, } \\
\text { Drachm }\end{array}$ & Found after 1970 & $\begin{array}{l}\text { BMC 9; } \\
\text { SNG Cop. 45 }\end{array}$ & $\begin{array}{l}\text { Museum in } \\
\text { Koszalin }\end{array}$ \\
\hline
\end{tabular}

Tab. 2. Bronze Roman Provincial Coins in Lesser Poland

\begin{tabular}{|c|c|c|c|c|c|c|c|c|c|}
\hline No. & Findspot & $\begin{array}{l}\text { Type } \\
\text { of coin find }\end{array}$ & $\begin{array}{l}\text { Mint / } \\
\text { Province }\end{array}$ & Issuer & Dates & $\begin{array}{l}\text { Denomi- } \\
\text { nation }\end{array}$ & Remarks & References & Collection \\
\hline \multicolumn{10}{|c|}{ Macedonia } \\
\hline 1 & $\begin{array}{l}\text { Gródek, } \\
\text { Hrubieszów } \\
\text { District }\end{array}$ & Stray find & Philippi & $\begin{array}{l}\text { August } \\
(27 \mathrm{BC}- \\
14 \mathrm{AD})\end{array}$ & $\begin{array}{l}27 \mathrm{BC}- \\
14 \mathrm{AD}\end{array}$ & $\mathrm{AE}$ & $\begin{array}{l}\text { Accidental find. } \\
\text { Context unknown. }\end{array}$ & & unknown \\
\hline 2 & $\begin{array}{l}\text { Opatkowice, } \\
\text { Proszowice } \\
\text { District }\end{array}$ & Stray find & Macedonia & $\begin{array}{l}\text { Autono- } \\
\text { mous }\end{array}$ & $242 \mathrm{AD}$ & $\mathrm{AE}$ & $\begin{array}{l}\text { Accidental find. } \\
\text { Context unknown. }\end{array}$ & & unknown \\
\hline \multicolumn{10}{|c|}{ Dacia } \\
\hline 3 & $\begin{array}{l}\text { Brzezie, } \\
\text { Wieliczka District }\end{array}$ & Stray find & Apulum & \begin{tabular}{|l|} 
Philip I \\
Arab \\
$(244-249)$
\end{tabular} & $246 / 7 \mathrm{AD}$ & $\begin{array}{l}\mathrm{AE}, \\
\text { sestertius }\end{array}$ & $\begin{array}{l}\text { Found on } \\
05.07 .2005 \text { during } \\
\text { archaeological ex- } \\
\text { cavation at Roman } \\
\text { Period settlement } \\
\text { (Brzezie site } 33 \text { ). } \\
\text { In the gray layer } \\
\text { no. } 612 \text {, in the } \\
\text { eastern part of the } \\
\text { site. }\end{array}$ & Martin 2.81.1 & $\begin{array}{l}\text { The Archae- } \\
\text { ological } \\
\text { Museum in } \\
\text { Kraków }\end{array}$ \\
\hline \multicolumn{10}{|c|}{ Thrace } \\
\hline 4 & $\begin{array}{l}\text { Jakuszowice, } \\
\text { Kazimierza } \\
\text { Wielka District }\end{array}$ & Stray find & Anchialos & \begin{tabular}{|l|} 
Antoni- \\
nus Pius \\
$(138-161)$
\end{tabular} & 138-161 AD & $\mathrm{AE}$ & $\begin{array}{l}\text { Found accidently } \\
\text { (?) to the south of } \\
\text { the road leading } \\
\text { from Kazimierza } \\
\text { Wielka to Krzyż } \\
\text { (site 2) after } 1997\end{array}$ & $\begin{array}{l}\text { AMNG II } \\
414, \\
\text { Varbanov } 42\end{array}$ & unknown \\
\hline \multicolumn{10}{|c|}{ Moesia Superior } \\
\hline 5 & $\begin{array}{l}\text { Jakuszowice, } \\
\text { Kazimierza } \\
\text { Wielka District }\end{array}$ & Stray find & Viminacium & $\begin{array}{l}\text { Trebo- } \\
\text { nianus } \\
\text { Gallus } \\
(251- \\
253)\end{array}$ & 251-253 AD & $\begin{array}{l}\mathrm{AE}, \\
\text { sestertius }\end{array}$ & $\begin{array}{l}\text { Found during } \\
\text { archaeological } \\
\text { research. Surface } \\
\text { find in } 1995\end{array}$ & Pick 168 & $\begin{array}{l}\text { Institute of } \\
\text { Archaeo- } \\
\text { logy, The } \\
\text { Jagiellonian } \\
\text { University in } \\
\text { Kraków }\end{array}$ \\
\hline
\end{tabular}


JAROSŁAW BODZEK, SZYMON JELLONEK, BARBARA ZAJĄC

\begin{tabular}{|c|c|c|c|c|c|c|c|c|c|}
\hline 6 & $\begin{array}{l}\text { Hrubieszów, } \\
\text { District loco }\end{array}$ & $\begin{array}{l}\text { Stray find } \\
\text { or part of } \\
\text { hoard? }\end{array}$ & Viminacium & $\begin{array}{l}\text { Philip I } \\
\text { Arab } \\
(244-249)\end{array}$ & 244-249 AD & $\mathrm{AE}$ & $\begin{array}{l}\text { Found in } 2005 \text {. } \\
\text { Uncertain context } \\
\text { - with other coins, } \\
\text { metal artefacts } \\
\text { and pottery? }\end{array}$ & $\begin{array}{l}\text { SNG Cop. } \\
152\end{array}$ & unknown \\
\hline 7 & Kraków-Podgórze & Stray find & Viminacium & $\begin{array}{l}\text { Hostilian } \\
(251)\end{array}$ & $251 \mathrm{AD}$ & $\begin{array}{l}\mathrm{AE}, \\
\text { sestertius }\end{array}$ & $\begin{array}{l}\text { Found before } \\
\text { 1824; context } \\
\text { unknown }\end{array}$ & Martin 4.01.1 & $\begin{array}{l}\text { The Jagiello- } \\
\text { nian Univer- } \\
\text { sity Museum, } \\
\text { inv. No }\end{array}$ \\
\hline 8 & $\begin{array}{l}\text { Kraków, } \\
\text { Warszawska Str. }\end{array}$ & Hoard? & Viminacium & $\begin{array}{l}\text { Trebo- } \\
\text { nianus } \\
\text { Gallus } \\
(251-253)\end{array}$ & 251-253 AD & $\begin{array}{l}\mathrm{AE}, \\
\text { sestertius }\end{array}$ & $\begin{array}{l}\text { Uncertain find, } \\
\text { part of the hoard? }\end{array}$ & Martin 5.01.1 & $\begin{array}{l}\text { The National } \\
\text { Museum in } \\
\text { Krakow; inv. } \\
\text { no MNK VII-A- }\end{array}$ \\
\hline 9 & $\begin{array}{l}\text { Kraśnik Fabry- } \\
\text { czny (cuurently } \\
\text { part of Kraśnik, } \\
\text { District loco) }\end{array}$ & Stray find & Viminacium & $\begin{array}{l}\text { Philip I } \\
\text { Arab } \\
(244-249)\end{array}$ & $245 \mathrm{AD}$ & $\begin{array}{l}\mathrm{AE}, \\
\text { sestertius }\end{array}$ & Found in 1954 & Pick 103 & unknown \\
\hline 10 & $\begin{array}{l}\text { Tarnów, District } \\
\text { loco }\end{array}$ & Stray find & Viminacium & $\begin{array}{l}\text { Trebo- } \\
\text { nianus } \\
\text { Gallus } \\
(251-253)\end{array}$ & $252-253 \mathrm{AD}$ & $\begin{array}{l}\mathrm{AE}, \\
\text { sestertius }\end{array}$ & Found in 1964 & Pick 165 & $\begin{array}{l}\text { Tarnów Dis- } \\
\text { trict Museum; } \\
\text { inv. No. MT- } \\
\text { N/712 }\end{array}$ \\
\hline 11 & $\begin{array}{l}\text { Tomaszów } \\
\text { Lubelski, } \\
\text { District loco }\end{array}$ & Stray find & Viminacium & $\begin{array}{l}\text { Trajan } \\
\text { Decius } \\
(249-251)\end{array}$ & $249-251 \mathrm{AD}$ & $\mathrm{AE}$ & Bad preservation & & unknown \\
\hline \multicolumn{10}{|c|}{ Bosporan Kingdom } \\
\hline 12 & $\begin{array}{l}\text { Gorlice-Glinik } \\
\text { Mariampolski, } \\
\text { Gorlice district }\end{array}$ & Hoard & $\begin{array}{l}\text { Cimmerian } \\
\text { Bosporus }\end{array}$ & $\begin{array}{l}\text { Rhe- } \\
\text { scuporis } \\
\text { II (68/69- } \\
91 / 92)\end{array}$ & 80-93 AD & $\begin{array}{l}\mathrm{AE}, \\
\text { sestertius }\end{array}$ & $\begin{array}{l}\text { Found in } 1937 . \text { In } \\
\text { a hoard of about } \\
200 \mathrm{AE} \text {; including } \\
\text { nos } 13,17,26 .\end{array}$ & $\begin{array}{l}\text { Frolova } \\
\text { 1997a: 105, } \\
\text { 1st group, pl. } \\
\text { XXXI, 4-15 }\end{array}$ & Private \\
\hline 13 & $\begin{array}{l}\text { Gorlice-Glinik } \\
\text { Mariampolski, } \\
\text { Gorlice District }\end{array}$ & Hoard & $\begin{array}{l}\text { Olbia, } \\
\text { Sarmatia }\end{array}$ & $\begin{array}{l}\text { Autono- } \\
\text { mous }\end{array}$ & $\begin{array}{l}\text { mid-2nd } \\
\text { cent. AD }\end{array}$ & $\mathrm{AE}$ & $\begin{array}{l}\text { Found in } 1937 . \text { In } \\
\text { a hoard of about } \\
200 \mathrm{AE} \text {; including } \\
\text { nos } 12,17,26 .\end{array}$ & $\begin{array}{l}\text { Karshkovskii } \\
\text { 1988: Pl. } \\
10.7\end{array}$ & Private \\
\hline 14 & $\begin{array}{l}\text { Nowy Sącz- } \\
\text { Zabełcze?, } \\
\text { environs }\end{array}$ & Stray find? & $\begin{array}{l}\text { Cimmerian } \\
\text { Bosporus }\end{array}$ & $\begin{array}{l}\text { Polemon } \\
(15-9)\end{array}$ & $15-9 \mathrm{BC}$ & $\mathrm{AE}$ & $\begin{array}{l}\text { Accidental find. } \\
\text { Found before } \\
1953 ?\end{array}$ & $\begin{array}{l}\text { Frolova } \\
\text { 1997a: 42, } \\
\text { type III, pl. } \\
\text { XV, 15-16a }\end{array}$ & $\begin{array}{l}\text { The Nowy } \\
\text { Sącz District } \\
\text { Museum, inv. } \\
\text { No A/5 }\end{array}$ \\
\hline 15 & $\begin{array}{l}\text { Staniątki, } \\
\text { Wieliczka District }\end{array}$ & Stray find? & $\begin{array}{l}\text { Cimmerian } \\
\text { Bosporus }\end{array}$ & $\begin{array}{l}\text { Rhescu- } \\
\text { poris III } \\
(211 / 12- \\
228 / 9)\end{array}$ & 211-215 AD & $\begin{array}{l}\text { AE, } \\
\text { denarius }\end{array}$ & $\begin{array}{l}\text { Found in } 1868 \text {, } \\
\text { during construc- } \\
\text { tion of the Lesser } \\
\text { Poland railroad }\end{array}$ & $\begin{array}{l}\text { Frolova } \\
\text { 1997b: 10; } \\
\text { pl. XIV, 7-10 }\end{array}$ & $\begin{array}{l}\text { The Archaeo- } \\
\text { logical Muse- } \\
\text { um in Kraków, } \\
\text { inv. No. } \\
\text { MAK/10521 }\end{array}$ \\
\hline 16 & $\begin{array}{l}\text { Zarzecze, Prze- } \\
\text { worsk District }\end{array}$ & Stray find? & $\begin{array}{l}\text { Cimmerian } \\
\text { Bosporus }\end{array}$ & $\begin{array}{l}\text { Cotys I } \\
(45-68)\end{array}$ & 63-68 AD & $\begin{array}{l}\text { AE, } \\
\text { dupondius }\end{array}$ & $\begin{array}{l}\text { Found in } 1882 \text {, } \\
\text { during construc- } \\
\text { tion of the Lesser } \\
\text { Poland railroad }\end{array}$ & $\begin{array}{l}\text { Frolova } \\
\text { 1997a: } 100, \\
\text { type 1, pl. } \\
\text { XXVIII, } \\
11-18\end{array}$ & $\begin{array}{l}\text { The Archaeo- } \\
\text { logical Muse- } \\
\text { um in Kraków, } \\
\text { inv. No. MAK } \\
10556\end{array}$ \\
\hline \multicolumn{10}{|c|}{ Crete } \\
\hline 17 & $\begin{array}{l}\text { Gorlice-Glinik } \\
\text { Mariampolski, } \\
\text { Gorlice District }\end{array}$ & Hoard & Cnossos & $\begin{array}{l}\text { Cydas, } \\
\text { archon }\end{array}$ & c. $36 \mathrm{BC}$ & $\mathrm{AE}$ & $\begin{array}{l}\text { Found in 1937. In } \\
\text { a hoard of about } \\
200 \mathrm{AE} \text {; including } \\
\text { nos } 12-13 \text { and } 17 .\end{array}$ & $\begin{array}{l}\text { Chapmann } \\
\text { 1968: 13ff; } \\
\text { RPC I } 934\end{array}$ & Private \\
\hline \multicolumn{10}{|c|}{ Asia Minor } \\
\hline 18 & $\begin{array}{l}\text { Gorlice-Glinik } \\
\text { Mariampolski, } \\
\text { Gorlice District }\end{array}$ & Hoard & $\begin{array}{l}\text { Korykos, } \\
\text { Cilicia }\end{array}$ & & $\begin{array}{l}\text { 1st cent. } \\
\text { BC-early } \\
\text { imperial } \\
\text { period }\end{array}$ & $\mathrm{AE}$ & $\begin{array}{l}\text { Found in } 1937 . \\
\text { including nos } 12, \\
13 \text { and } 26 .\end{array}$ & $\begin{array}{l}\text { SNG France } \\
1086-1093\end{array}$ & Private \\
\hline 19 & $\begin{array}{l}\text { Jakuszowice, } \\
\text { Kazimierza } \\
\text { Wielka District }\end{array}$ & Stray find & $\begin{array}{l}\text { Caesarea, } \\
\text { Cappadocia }\end{array}$ & $\begin{array}{l}\text { Caracalla } \\
(211-217)\end{array}$ & 211-217 AD & $\mathrm{AE}$ & $\begin{array}{l}\text { Found during } \\
\text { archaeological } \\
\text { research. Surface } \\
\text { find in } 1993\end{array}$ & BMC 271 & $\begin{array}{l}\text { Institute of Ar- } \\
\text { chaeology, the } \\
\text { Jagiellonian } \\
\text { University, } \\
\text { Kraków }\end{array}$ \\
\hline
\end{tabular}


ROMAN PROVINCIAL COINS FOUND IN LESSER POLAND: AN OVERVIEW

\begin{tabular}{|c|c|c|c|c|c|c|c|c|c|}
\hline 20 & $\begin{array}{l}\text { Zabrodzie, } \\
\text { Zawiercie District }\end{array}$ & Stray find & Temnos & $\begin{array}{l}\text { Autono- } \\
\text { mous }\end{array}$ & $117-268 \mathrm{AD}$ & $\mathrm{AE}$ & & $\begin{array}{l}\text { SNG Cop. } \\
\text { 274; SNG v. } \\
\text { Aulock } 1677\end{array}$ & unknown \\
\hline \multicolumn{10}{|c|}{ Syria } \\
\hline 21 & $\begin{array}{l}\text { Nowa Słupia, } \\
\text { Kielce District }\end{array}$ & Stray find & $\begin{array}{l}\text { Caesarea } \\
\text { Palestinae }\end{array}$ & $\begin{array}{l}\text { Nero } \\
(54-68)\end{array}$ & 67-68 AD & $\mathrm{AE}$ & Found in 1981 & BMC 13-29 & $\begin{array}{l}\text { The Archae- } \\
\text { ological and } \\
\text { Ethnograph- } \\
\text { ical Museum } \\
\text { in Łódź }\end{array}$ \\
\hline 22 & $\begin{array}{l}\text { Wąchock, } \\
\text { Starachowice } \\
\text { District }\end{array}$ & Stray find & Tyre & \begin{tabular}{|l|} 
Elagaba- \\
lus \\
$(218-222)$
\end{tabular} & 218-222 AD & $\mathrm{AE}$ & & BMC 397 & $\begin{array}{l}\text { The Archae- } \\
\text { ological and } \\
\text { Ethnograph- } \\
\text { ical Museum } \\
\text { in Łódź }\end{array}$ \\
\hline 23 & $\begin{array}{l}\text { Zarzecze, } \\
\text { Przeworsk District }\end{array}$ & Stray find? & Ascalon & $\begin{array}{l}\text { Autono- } \\
\text { mous }\end{array}$ & $\begin{array}{l}1^{\text {st }}-2^{\text {nd }} \text { centu- } \\
\text { ry AD }\end{array}$ & $\mathrm{AE}$ & $\begin{array}{l}\text { Found with } \\
\text { bronze coin of } \\
\text { Cotys I? }\end{array}$ & $\begin{array}{l}\text { SNG Cop. 35, } \\
\text { RPC I 4882- } \\
4883\end{array}$ & $\begin{array}{l}\text { The Archaeo- } \\
\text { logical Muse- } \\
\text { um in Kraków }\end{array}$ \\
\hline \multicolumn{10}{|c|}{ Egypt } \\
\hline 24 & $\begin{array}{l}\text { Chełm, } \\
\text { district loco }\end{array}$ & Hoard & Alexandria & \begin{tabular}{|l} 
Probus \\
$(276-282)$
\end{tabular} & 276-282 AD & $\begin{array}{l}\text { AE, } \\
\text { Tetra- } \\
\text { drachm }\end{array}$ & $\begin{array}{l}\text { Found before } \\
1914 \text { in a hoard of } \\
\text { c. } 200 \text { Greek- } \\
\text {-Imperial coins, } \\
\text { supposedly mostly } \\
\text { Alexandrian tet- } \\
\text { radrachms, includ- } \\
\text { ing nos 31-34. }\end{array}$ & & $\begin{array}{l}\text { The National } \\
\text { Museum in } \\
\text { Krakow? }\end{array}$ \\
\hline 25 & $\begin{array}{l}\text { Chełm, } \\
\text { district loco }\end{array}$ & Hoard & Alexandria & \begin{tabular}{|l} 
Carus \\
$(282-283)$
\end{tabular} & 282-283 AD & $\begin{array}{l}\text { AE, } \\
\text { Tetra- } \\
\text { drachm }\end{array}$ & $\begin{array}{l}\text { Found before } \\
1914 \text { in a hoard of } \\
\text { c. } 200 \text { Greek- } \\
\text {-Imperial coins, } \\
\text { supposedly most- } \\
\text { ly Alexandrian } \\
\text { tetradrachms, } \\
\text { including nos } 30 \text {, } \\
\text { 32-34. }\end{array}$ & & $\begin{array}{l}\text { The National } \\
\text { Museum in } \\
\text { Krakow? }\end{array}$ \\
\hline 26 & $\begin{array}{l}\text { Chełm, } \\
\text { district loco }\end{array}$ & Hoard & Alexandria & $\begin{array}{l}\text { Numerian } \\
(283-284)\end{array}$ & 283-284 AD & $\begin{array}{l}\text { AE, } \\
\text { Tetra- } \\
\text { drachm }\end{array}$ & $\begin{array}{l}\text { Found before } 1914 \\
\text { in a hoard of c. } \\
200 \text { Greek- } \\
\text {-Imperial coins, } \\
\text { supposedly mostly } \\
\text { Alexandrian tet- } \\
\text { radrachms, includ- } \\
\text { ing nos 30-31 and } \\
33 \text {-34. }\end{array}$ & Milne 4739 & unknown \\
\hline 27 & $\begin{array}{l}\text { Chełm, } \\
\text { district loco }\end{array}$ & Hoard & Alexandria & $\begin{array}{l}\text { Diocletian } \\
(284-305)\end{array}$ & 290-291 AD & $\begin{array}{l}\text { AE, } \\
\text { Tetra- } \\
\text { drachm }\end{array}$ & $\begin{array}{l}\text { Found before } \\
1914 \text { in a hoard of } \\
\text { c. } 200 \text { Greek- } \\
\text {-Imperial coins, } \\
\text { supposedly most- } \\
\text { ly Alexandrian } \\
\text { tetradrachms, } \\
\text { including nos } \\
\text { 30-32 and } 34 \text {. }\end{array}$ & Milne 4968 & unknown \\
\hline 28 & $\begin{array}{l}\text { Chełm, } \\
\text { district loco }\end{array}$ & Hoard & Alexandria & $\begin{array}{l}\text { Maximian } \\
\text { Herculius } \\
(285-305)\end{array}$ & 287-288 AD & $\begin{array}{l}\text { AE, } \\
\text { Tetra- } \\
\text { drachm }\end{array}$ & $\begin{array}{l}\text { Found before } \\
1914 \text { in a hoard of } \\
\text { c. } 200 \text { Greek- } \\
\text {-Imperial coins, } \\
\text { supposedly mostly } \\
\text { Alexandrian tetr- } \\
\text { adrachms, includ- } \\
\text { ing nos 30-33. }\end{array}$ & Milne 4860 & unknown \\
\hline 29 & $\begin{array}{l}\text { Włodawa, } \\
\text { District loco }\end{array}$ & $\begin{array}{l}\text { Hoard? } \\
\text { Stray find? }\end{array}$ & Alexandria & $\begin{array}{l}\text { Maximian } \\
\text { Herculius } \\
\text { (285-305) }\end{array}$ & 288-289 AD & $\begin{array}{l}\text { AE, } \\
\text { Tetra- } \\
\text { drachm }\end{array}$ & $\begin{array}{l}\text { Found before } \\
\text { 1958. A part } \\
\text { of hoard from } \\
\text { Chełm? }\end{array}$ & Milne 4921 & $\begin{array}{l}\text { Community } \\
\text { Center at } \\
\text { Włodawa? }\end{array}$ \\
\hline
\end{tabular}



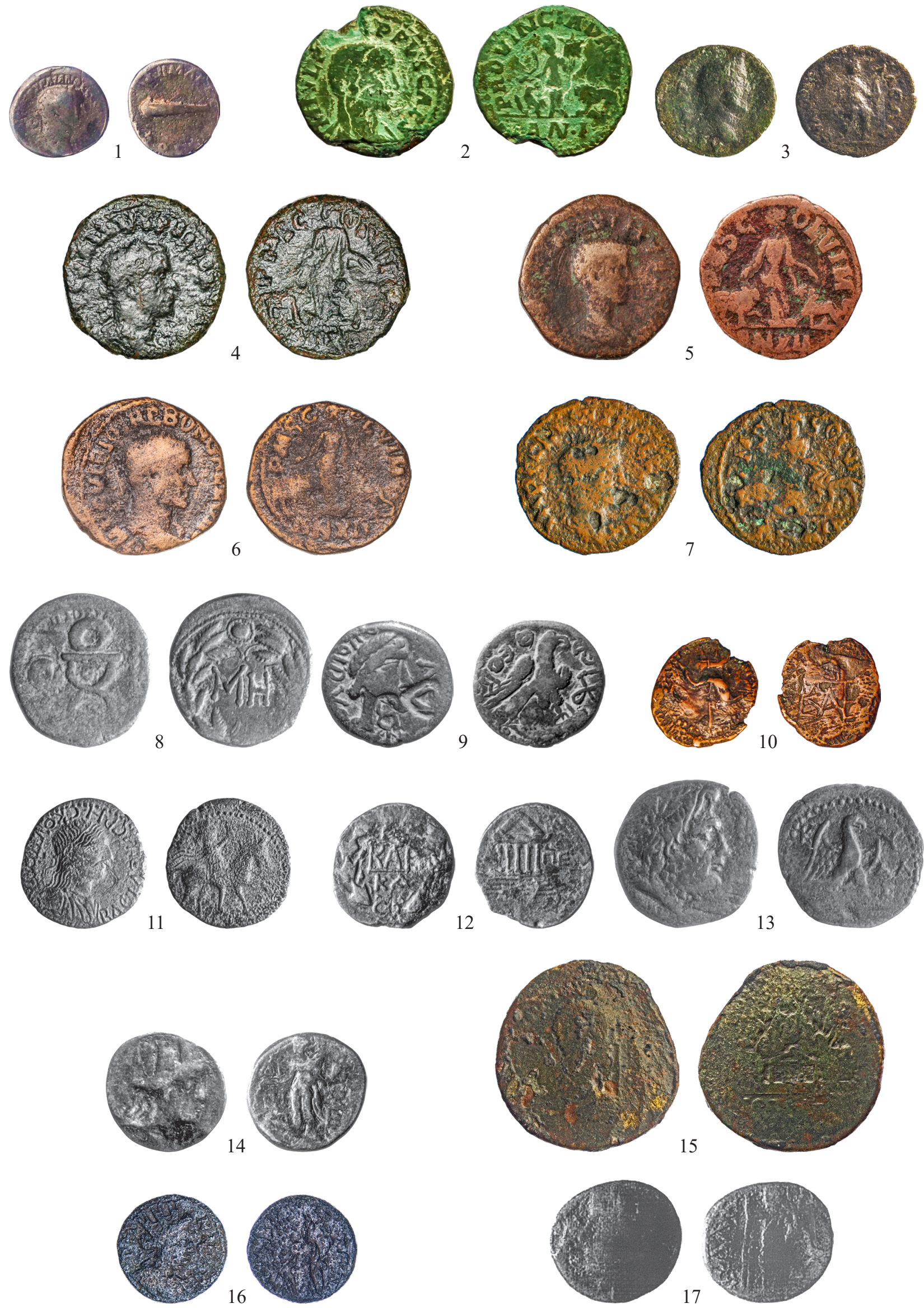

Plate 1

1. Nietulisko Małe, Ostrowiec District, Cappadocia, Caesarea, Trajan (98-117), AD 113/114-114/115, AR, Drachm (Photo: Tuco); 2. Brzezie, Wieliczka District, Dacia, Apulum, Philip I Arab (244-249), AE, sestertius (Photo: Tuco); 3. Jakuszowice, Kazimierza Wielka District, Thrace, Anchialos, Antoninus Pius (138-161), AE 
(Photo: M. Rudnicki); 4. Jakuszowice, Kazimierza Wielka District, Moesia Superior, Viminacium, Trebonianus Gallus (251-253), AE, sestertius (Photo: Tuco); 5. Kraków-Podgórze, Moesia Superior, Viminacium, Hostilian (251), AE, sestertius (Photo: The Jagiellonian University Museum); 6. Kraków, Warszawska Str., Moesia Superior, Viminacium, Trebonianus Gallus (251-253), AE, sestertius (Photo: Barbara Solarewicz); 7. Tarnów, District loco,

Moesia Superior, Viminacium, Trebonianus Gallus (251-253), AE, sestertius (Photo: Robert Moździerz); 8. Gorlice-

-Glinik Mariampolski, Cimmerian Bosporus, Rhescuporis II (68/69-91/92), AD 80-83, AE, sestertius (Photo:

Konrad Pollesch); 9. Gorlice, Glinik Mariampolski, Sarmatia, Olbia, c. mid-2nd cent. AD, AE (Photo: Konrad

Pollesch); 10. Nowy Sącz-Zabełcze?, environs, Cimmerian Bosporus, Polemon (15-9) (Photo: Bartłomiej Urbański);

11. Staniątki, Wieliczka District, Cimmerian Bosporus, Rhescuporis III (211/12-228/9), AE, denarius (Photo:

Archaeological Museum in Krakow); 12. Zarzecze, Przeworsk District, Cimmerian Bosporus, Cotys I (45-69),

AD 63-69, AE, dupondius (Photo: Archaeological Museum in Krakow); 13. Gorlice, Glinik Mariampolski; Crete,

Cnossos, archon Cydas, c. 36 BC, AE (Photo: Konrad Pollesch); 14. Gorlice, Glinik Mariampolski; Cilicia,

Korykos: 1st cent. BC - early imperial period, AE (Photo: Konrad Pollesch); 15. Jakuszowice, Kazimierza Wielka

District, Cappadocia, Caesarea, Caracalla (211-217), AE (Photo: Tuco); 16. Zabrodzie, Zawiercie District, Asia,

Temnos, Autonomous (117-268), AE (Photo: Tuco); 17. Zarzecze, Przeworsk District, Syria, Ascalon, Autonomous 1-2nd century AD, AE (Photo: Archaeological Museum in Krakow)

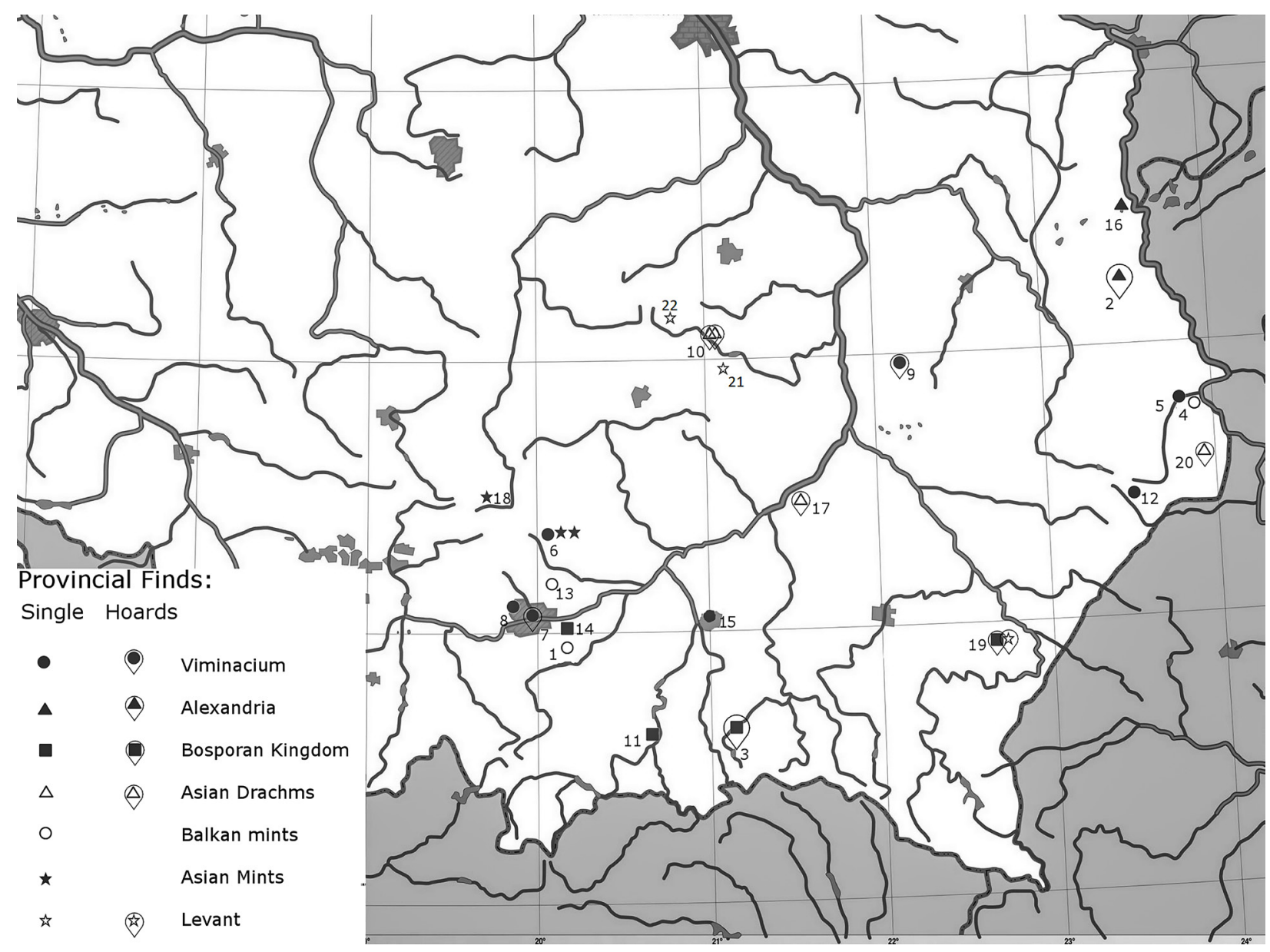

Map 1: Distribution of Roman Provincial Coins in Lesser Poland.

1. Brzezie, 2. Chełm, 3. Gorlice-Glinik Mariampolski, 4. Gródek, 5. Hrubieszów, 6. Jakuszowice, 7. Kraków Podgórze, 8. Kraków ul. Warszawska, 9. Kraśnik Fabryczny,

10. Nietulisko Małe, 11. Nowy Sącz, 12. Tomaszów Lubelski, 13. Opatkowice,

14. Staniątki, 15. Tarnów, 16. Włodawa, 17. Wojków, 18. Zabrodzie, 19. Zarzecze, 20. Żulice, 21. Nowa Słupia, 22. Wąchock 
Abbreviations

\section{$A M N G$ II}

Münzer F. and Max L. Strack M.L. (eds.) Die Antiken Münzen Nord-Griechenlands. Band II. Thrakien (Berlin 1912-).

FMRD, abt. 3, Saarland

Kienast D. (ed.) 1962. Die Fundmünzen der römischen Zeit in Deutschland, Abt. 3. Saarland, Frankfurt am Main.

FMRD abt. 5, bd 2,1: Hessen

Schubert H. (ed.) 1989. Die Fundmünzen der römischen Zeit in Deutschland, Abt. 5. Hessen. Band 2,1 Darmstadt, Frankfurt am Main.

FMRD, abt. 5, bd 3: Hessen

Schubert H. (ed.) 2003. Die Fundmünzen der römischen Zeit in Deutschland, Abt. 5. Hessen. Band 3. Kassel, Frankfurt am Main.

Pick

Pick B. 1898-1910. Die antike Münzen von Dacien und Moesien, T. 1. 2. Berlin.

SNG Cop.

Sylloge Nummorum Graecorum, The Royal Collection of Coins and Medals, The Danish National Museum, (reedition Sunrise Publications Inc. West Milford, New Jersey 1982).

Vol 2: Thrace and Macedonia;

Vol 5: Ionia, Caria and Lydia

SNG v. Aulock

Sylloge Nummorum Graecorum, Deutschland, Sammlung Hans Von Aulock, Vol. 1: Pontus, Paphlagonia, Bithynia, Mysia, Troas, Aiolis, Lesbos, Ionia (Berlin, 1957).

Varbanov

Varbanov I. 2002. Greek Imperial Coins and Their Values: The Local Coinages of the Roman Empire, Vol. I-III, Burgas.

\section{Literature}

Amandry M. 2012. The Coinage of the Roman Provinces through Hadrian. In. W.M. Metcalf (ed.), The Coinage of the Roman Provinces through Hadrian, Oxford, 391-404.

Anokhin V.A. 1986. Monetnoe delo Bospora, Kiev.

Anonim 1916. Wiadomości Numizmatyczno-Archeologiczne 6, 60 .

Anonim 1936. Skarb monet rzymskich znaleziony $w$ Osie, Wiadomości Numizmatyczno-Archeologiczne 18, 156.

Antoniewicz J. 1955. Brazowa moneta cesarza Galiena, znaleziona w miejscowości Kuty, pow. Wegorzewo, Wiadomości Archeologiczne 22, 358-360.
Bandtkie J.S. 1824-1825. Nummi veteri in Polonia reperti. In. Index lectionum in Universitate Studiorum Jagellonica, Kraków.

Bar M. 1985. Les monnaies grecques de Césarée de Cappadoce (Ier-IIIe s. Ap. J-C.) trouvée en Europe, Bulletin du Cercles d'Études numismatiques 22/3, 53-65.

Bartkowiak Z. 2006. Jasienica Górna, gm. i pow. Nysa, Wiadomości Numizmatyczne 50/1, 97.

Beidin G.V. 2012. Rimskie provintsionalnye monety na territorii Ukrainy $v$ areale chernyakhovskoi kul'tury, Drevnosti 11, 147-159.

Beidin G.V. 2017. Nakhodki bosporskikh monet na territorii Vostochnogo Barbarikuma: monety serediny I v. do n.e. - kontsa 30-kh gg. III v. n.e. In. Zapiski viddilu numizmatiki torevtiki Odes'kogo arkheologichnogo muzeyu III, Odesa, 25-49.

Beidin G.V. 2018. Nakhodki bosporskikh monet za peredelami severnogo Prichernomor'ya na territorii vostochnogo Barbarikuma: problemy izucheniya. In. M. Lyubichev and K. Myzgin (eds.), Ostrogothica III. Khronologiya i monetnye nakhodki pozdnerimskogo vremeni $i$ epokhi velikogo pereseleniya narodov. Aktual'nye arkheologicheskie issledovaniya $v$ tsentralnoi $i$ vostochnoi Evrope, Khar'kov, 12-35.

Beidin G.V. and Myzgin K.V. 2015. Klad pozdnebosporskikh mednykh staterov iz Ksizovo. In. A.M. Oblomskii (ed.), Ostraya Luka Dona $v$ drevnosti. Arkheologicheskii kompleks pamyatnikov gunnskogo vremeni u s. Ksizovo (konets $I V-V v v$.)(Raneslavyanskii mir. Vyp. 16), Moskva, 165-180.

Beidin G.V., Grigor'iantis M.N. and Liubichev M.V. 2006. Nakhodki monet rimskogo vremeni na territorii Khar'kovskoi oblasti. In. A.N. Zinukhov (ed.), Drevnosti rimskogo vremeni na Slobozhanshchine, Khar'kov, 110-143.

Bełkowska I. 1981. Napływ dużych monet brazowych na ziemie polskie w I-III w. n.e., Wiadomości Numizmatyczne 25, 121-153.

Bezzenberger A. 1904. Analysen vorgeschichtlicher Bronzen Ostpreussens, Königsberg.

Bodzek J. 2004. Drachma Cezarei kapadockiej ze skarbu denarów Nietulisko Małe I. In. W. Kaczanowicz (ed.), Studia z dziejów antyku. Pamięci Andrzeja Kunisza, Katowice, 142-152.

Bodzek J. 2007. Dawne i nowe znaleziska monet rzymskich warchiwum i zbiorze Muzeum Narodowego w Krakowie (cz. I), Wiadomości Numizmatyczne 51/1, 79-87.

Bodzek J. 2018. Starożytne monety rzymskie znalezione w Stanisławicach, stan. 9, gm. Bochnia, 
woj. Małopolskie. In J. Rodak (ed.), Stanisławice, stan 9 i 10, pow. bocheński. Osady z okresu wplywów rzymskich i czasów nowożytnych. Via Archeologica. Źródła z badań wykopaliskowych na trasie autostrady A4 w Małopolsce, Kraków, 187-194.

Bodzek J. and Madyda-Legutko R. 1997. The Ascalon Coin found at Zarzecze, Przemyśl Voivodship, Notae Numismaticae - Zapiski Numizmatyczne III/IV, 141-152.

Bodzek J. and Madyda-Legutko R. 2013. Novaya nakhodka bosporskoi monety v Polshe, Drevnee Prichernomor'e, Vypusk X, 69-72.

Bodzek J. and Madyda-Legutko R. 2018. Coins of the Rulers of Cimmerian Bosporus found in Poland, Notae Numismaticae - Zapiski Numizmatyczne XIII, 53-92.

Bodzek J., Smagur E., Lach K. and Kopij K. 2014. The database ,Finds of Roman Coins in Poland" as a new open source tool. The progress in cataloguing coins from Lesser Poland. In. D. Dreslerova (ed.), Pocitacova podpora $v$ archeologii/Computer Application in Archaeology XIII, Svratka, 28.-30.5.2014. Abstract book, Praha, 49.

Bodzek J., Kopij K. and Smagur E. 2017. Finds of Roman Coins in Poland - Lesser Poland. Preliminary Report. In. M. Caccamo Caltabiano et al. (eds.), XV International Numismatic Congress Taormina 2015 Proceedings, Taormina, Roma-Messina, 825-829.

Bodzek J., Jellonek Sz. and Zając B. 2018. Projekt „Roman Coins Finds from Poland and Territory Associated Historically with Poland" (FRC PL) i nowe znaleziska monet rzymskich $z$ Matopolski. In. V.M. Sidarovich (ed.), Tretsiya navukoviya chitanni pamyatsi prafesara Valyantsina Navumovicha Pabtsevicha (19342008). Tezisi dakladay, Minsk, 16-18 maya 2018 g., Minsk 2018, 8.

Bogucki M., Jagodziński M.F. and Wiercińska J. 2006. Łęcze, gm. Tolkmicko, pow. elblaski, woj. warmińsko-mazurskie, Wiadomości Numizmatyczne 50/2, 201.

Bogucki M., Jurkiewicz B. and Machajewski H. 2012. Licyjska drachma Trajana z osady przeworskiej z miejscowości Łęki Majątek pow. Kutnowski, Wiadomości Numizmatyczne 56/2, 236-243.

Bolin S. 1926a. Fynden av romerska mynt i det fria Germanien. Studier i romersk och äldre Germansk historia, Lund.

Bolin S. 1926b. Die Funde römischer und byzantinischer Münzen in Ostpreussen, Prussia XXVI, 203-240.
Borić-Brešković B. and Vojvoda M. 2018. The Circulation of Roman Provincial Coins from the Viminacium Mint. In. M. Korać, S. Golubović and N. Mrđić (eds.), Vivere Militare Est. From Populus to Emperors - Living on the Frontier, Institute of Archaeology Monographies 68/2, Belgrade, 73-100.

Brajcevskii M.Yu. 1959. Rims'ka moneta na terytorii Ukraini, Kiiv.

Budaj M. and Hunka J. 2018. Nálezy mincí na Slovensku V/1. Bratislava, Nitra.

Bursche A. 1983. „Medaillon” of Perinthos found near Gdańsk. In. A. Fol (ed.), Pulpudeva, Semaines Philippopolitaines de l'histoire et la culture Thrace, 4, Plovdiv, 3-17 Octobre 1980, Sofia, 197-199.

Bursche A. 1984. Emisje autonomiczne Mezji i Tracji oraz ich rozpowszechnienie $w$ Europie Środkowo-Wschodniej. In. S. Parnicki-Pudełko (ed.), Balcanica Posnaniensia, Acta et Studia, I, Mezja-Tracja-Batkany, Poznań, 235-244.

Bursche A. 1988. Znaleziska monet rzymskich $z$ Matopolski. Uwagi na marginesie inwentarza Andrzeja Kunisza, Wiadomości Numizmatyczne 32, 207-214.

Bursche A. 1994. Die Markomannenkriege und der Zufluß römischer Münzen in das Barbaricum. In. H. Friesinger, J. Tejral, A. Stuppner (eds.), Markomannenkriege. Ursachen und Wirkungen, Brno, 471-485.

Bursche A. 1996. Later Roman-Barbarian Contacts in Central Europe. Numismatic Evidence, Berlin.

Bursche A. 1997. Roman Coinage from Jakuszowice Settlement in North Małopolska, Notae Numismaticae - Zapiski Numizmatyczne II, 119-157.

Bursche A. 1999. Znane i nieznane znaleziska denarów z ziem polskich, Wiadomości Numizmatyczne 43, 115-145.

Bursche A. 2006. Relations between the Late Roman World and Barbarian Europe in the Light of Coin Finds, Bulletin du Cercle d'études numismatiques 43/2, 221-227.

Bursche A. 2007. Recenzja W. A. Łonak, Znaleziska monet rzymskich na Ślasku, Częstochowa 2005, Archeologia Polski LII, 209-214.

Bursche A. 2008. Function of Roman coins in Barbaricum of Later Antiquity. An anthropological essay. In. A. Bursche, R. Ciołek and R. Wolters (eds.), Roman coins outside the Empire. Ways and Phases, Contexts and Functions. Proceedings of the ESF/SCH Exploratory Workshop, Radziwitt Palace, Nieborów (Poland), 3-6 September 2005, Collection Moneta 82, Wetteren, 395-416. 
Bursche A. 2013. Recording the Roman Coin Finds from Poland, FRC PL 2013-2017, Notae Numismaticae - Zapiski Numizmatyczne VIII, 281-283. DOI: 10.11588/diglit.31072.32

Bursche A. 2014. Inwentarze znalezisk monet rzymskich z Polski (FMRPL) będa kontynuowane, Wiadomości Numizmatyczne 58/1-2, 347-349.

Bursche A., Kaczanowski P. and Rodzińska-Nowak J. 2000. Monety rzymskie z Jakuszowic. In. R. Madyda-Legutko and T. Bochnak (eds.), Superiores barbari. Ksiega ku czci Profesora Kazimierza Godłowskiego, Kraków, 101-130.

Bursche A. and Czarnecka K. 2006. Moneta Maksymiana Herkuliusza $z$ osady $w$ Oronnem, pow. garwolinski. In. A. Bursche and R. Ciołek (eds.), Corpus der römische Funde im europäischen Barbaricum. Polen. Supplement Band 3, Neue Funde römischer Importe aus Polen III, Warszawa, 215-218.

Butcher K. 1988. Roman Provincial Coins: An Introduction to the Greek Imperials, London.

Ciołek R. 2001. Katalog znalezisk monet rzymskich na Pomorzu. Światowit Supplement Series A: Antiquity VI, Warszawa.

Ciołek R. 2007. Die Fundmünzen der Römischen Zeit in Polen: Pommern, Collection Moneta 67, Wetteren.

Ciołek R. 2008. Die Fundmünzen der Römischen Zeit in Polen: Schlesien, Collection Moneta 83, Wetteren.

Dobrzańska H. 1997. Kultura przeworska w okresie rzymskim. In. K. Tunia (ed.), Z archeologii Małopolski. Historia i stan badań zachodniomałopolskiej wyżyny lessowej, Kraków, 331382.

Dušanić S. 1976. The Era of Viminacium. In. M. Vasić, P. Popović and D. Gaj-Popović (eds.), Kovanje i kovnice antičkog $i$ srednjovekovnog novca, Beograd, 53-58.

Dymowski A. 2008a. Najnowsze znaleziska monet rzymskich z Lubelszczyzny i Podkarpacia, Lubelskie Wiadomości Numizmatyczne 50, 36-68.

Dymowski A. 2008b. Najnowsze znaleziska monet rzymskich z północnej Polski, Gdańskie Zeszyty Numizmatyczne 74, 13-22.

Dymowski A. 2008c. Najnowsze znaleziska monet rzymskich z prawobrzeżnego Mazowsza i Podlasia, Wiadomości Numizmatyczne 52, 70-98.

Dymowski A. 2009. Najnowsze znaleziska monet rzymskich z Warszawy i okolic, Biuletyn Numizmatyczny 1 (353), 13-20.

Dymowski A. 2011. Znaleziska monet rzymskich rejestrowane $w$ pierwszych latach XXI wieku. Aspekty źródloznawcze, Zielona Góra.
Dymowski A. 2013. Chronologia napływu denarów rzymskich z I -III wieku na ziemie Polski $w$ świetle analizy nowego materiatu ze znalezisk drobnych, Wiadomości Numizmatyczne 57/1, 93-148.

Dymowski A. and Jellonek S. 2017. Mniej lub bardziej interesujace monety rzymskie znalezione niedawno na terenie Polski, Biuletyn Numizmatyczny 4 (388), 241-257.

Dymowski A. and Więcek T. 2018. Kolejne znaleziska monet antycznych z terenu Kujaw, Biuletyn Numizmatyczny 3 (391), 161-187.

Erdrich M. 2001. Rom und die Barbaren. Das Verhältnis zwischen dem Imperium Romanum und den germanischenn Stämmen vor sejner Nordwestgrenze vor der späten Republik bis zum Gallischen Sonderreich, Römisch-Germanische Forschungen 58, Mainz.

Feduszka J. 1999. Zamojska część skarbu monet rzymskich z Żulic, Wiadomości Numizmatyczne 43/1-2, 69-98.

Frolova N.A. 1997. Monetnoe delo Bospora (seredina I v. do n.e. - seredina IV v. n.e.), Chast' I. Monetnoe delo Bospora 49/49 g. do n.e.210/211 g. n.e., Chast' II. Monetnoe delo Bospora 211-341/342 gg. n. e., Moskva.

Gałęzowska A. 2016. Monety rzymskie w zbiorach Muzeum Archeologicznego w Poznaniu, Fontes Archaeologici Posnanienses 52, 207-254.

Găzdac C. 2008. Aspects of coin circulation in Roman Dacia. In. A. Bursche, R. Ciołek and R. Wolters (eds.), Roman coins outside the Empire. Ways and Phases, Contexts and Functions. Proceedings of the ESF/SCH Exploratory Workshop, Radziwitt Palace, Nieborów (Poland), 3-6 September 2005, Collection Moneta 82, Wetteren, 269-294.

Găzdac-Alföldy A. and Găzdac C. 2005. The role of coinage "Provincia Dacia" in the coin supply at the Lower Danube region (3rd c. AD). In. C. Alfaro, C. Marcos and P. Otero (eds.), Proceedings of the XIIIth International Numismatic Congress, Madrid, Spain, September 2003, Madrid, 651-661.

Găzdac C. and Alföldy-Găzdac Á. 2008. The Management of a Monetary Crisis? The ' $P M S$ COL VIM' and 'PROVINCIA DACIA' Coinages in the Roman Monetary Policy of the $3 \mathrm{rd}$ Century AD, Numismatische Zeitschrift 116117, 135-153.

Gumowski M. 1958. Moneta rzymska w Polsce, Przegląd Archeologiczny X (1954-1956), 87-149.

Gupieniec A. 1954. Przewodnik po dziale numizmatycznym Muzeum Archeologicznego w Lodzi. Starożytność i wczesne średniowiecze, Łódź. 
Gurba J. 1958. Kobylany pow. Opatów; Kunów pow. Opatów; Skaty pow. Opatów; Włodawa woj. Lubelskie, Wiadomości Numizmatyczne $2 / 2,47$.

Hlinka J., Kolníková E., Kraskovská L. and Novák J. 1978. Nálezy mincí na Slovensku III. Bratislava.

Hollack F. and Peiser E. 1904. Das Gräbefeld von Moythienen, Königsberg.

Howgego C. 2005. Coinage and Identity in the Roman Provinces. In. C. Howgego, V. Heuchert and A. Burnett (eds.), Coinage and Identity in the Roman Provinces, Oxford, 1-17.

Jančo M. 2002. Nález alexandrijských tetradrachiem v strednej Európe. Príspevok $k$ poznaniu obchodných kontaktov Afriky Prokonzulskej a Egypta so stredným Podunajskom v mladsej dobe rímskej, Slovenska numizmatika 16, $11-40$.

Jones T.B. 1963. A Numismatic Riddle: The So-called Greek Imperials, Proceedings of the American Philosophical Society 107/4, 308-347.

Jones T.B. 1965. Greek Imperial Coins, The Voice of the Turtle: North American Journal of Numismatics 4, 295-308.

Kaczanowski P. 2017. Corpus der römische Funde im europäischen Barbaricum. Polen-Band 2. Kleinpolen, Kraków.

Kaczanowski P. and Margos U. 2002. Tabula Imperii Romani, M 34-Kraków, Kraków.

Kisza W. 1990. Znaleziska monet rzymskich z terenu Polski w zbiorach Muzeum Uniwersytetu Jagiellońskiego, Opuscula Musealia 4, Zeszyty Naukowe Uniwersytetu Jagiellońskiego CMXLVIII, Kraków, 109-122.

Kokowski A. 1984. Monety antyczne na Lubelszczyźnie, Wiadomości Numizmatyczne 28/1-2, 27-54.

Kokowski A. 1995. Grupa masłomęcka. Z badań nad przemianami kultury Gotów w młodszym okresie rzymskim, Lublin.

Kokowski A. 1999. Strefy kulturowe w mtodszym okresie przedrzymskim $i w$ okresie rzymskim na tuku Karpat. Część I - od mtodszego okresu przedrzymskiego do młodszego okresu rzymskiego. In. S. Czopek and A. Kokowski (eds.), Na granicach antycznego świata, Rzeszów, 25-44.

Kolendo J. 2006. Jerzy Samuel Bandtkie autorem pionierskiej pracy z roku 1924 o znaleziskach monet rzymskich na ziemiach Polski. In. A. Bursche and R. Ciołek (eds.), Corpus der römische Funde im europäischen Barbaricum. Polen. Supplement Band 3, Neue Funde römischer Importe aus Polen III, Warszawa, 243-261.
Kolniková E. and Hunka J. 1994. Nálezy minci na Slovensku IV, Bratislava.

Konik E. 1965. Znaleziska monet rzymskich na Ślasku, Wrocław-Warszawa-Kraków.

Krzyżanowska A. 1976. Skarb denarów rzymskich z Drzewicza, Wrocław.

Kubiak S. 1978. Znaleziska monet greckich z obszaru Polski, Wiadomości Numizmatyczne 22/3-4, 190-217.

Kubiak S. 1979. Znaleziska monet rzymskich z Mazowsza i Podlasia, Wrocław.

Kunisz A. 1969. Chronologia naptywu pieniadza rzymskiego na ziemie Małopolski, Wrocław.

Kunisz A. 1970. Dalsze znaleziska monet rzymskich z Małopolski, Wiadomości Numizmatyczne 14, 126-128.

Kunisz A. 1973a. Katalog skarbów monet rzymskich odkrytych na ziemiach polskich, Warszawa.

Kunisz A. 1973b. East and Central European Finds of Autonomous Coins from the Roman Empire Period, Wiadomości Numizmatyczne 17, Polish Numismatic News 2, 27-39.

Kunisz A. 1979. Drachmy licyjskie i pontyjskie w obiegu monetarnym na europejskich obszarach Cesarstwa Rzymskiego. In. A. Kunisz (ed.), Pieniadz i gospodarka pieniężna w Starożytności i Średniowieczu, Historia i Współczesność $V$, Katowice, 65-93.

Kunisz A. 1983. Udzial drachm imperialnych $z$ Amisos $w$ obiegu pieniężnym na obszarze europejskich prowincji Cesarstwa rzymskiego w II-III w. n.e., Antiquitas 9, 123-131.

Kunisz A. 1985. Znaleziska monet rzymskich z Matopolski, Wrocław.

Laser R. 1980. Die römischen und frühbyzantinischen Fundmünzen auf dem Gebiet der DDR, Berlin.

Lind L. 1988. Romerska denara funna i Sverige, Stockholm.

Lucchelli T.M. 1998. La moneta nei rapporti tra Roma e l'Europa barbarica: aspetti e proble$m i$, Publicazioni della Facoltá di Lettere e Filosofia dell’Universitá degli Studi di Milano 179, Firenze.

Łonak W. 2005. Znaleziska monet rzymskich na Śląsu, Częstochowa.

Madyda-Legutko R. 1995. Zróżnicowanie kulturowe polskiej strefy beskidzkiej w okresie lateńskim i rzymskim. Katalog stanowisk, Rozprawy Habilitacyjne nr 304/2, Kraków.

Madyda-Legutko R. 1996a. Zróżnicowanie kulturowe polskiej strefy beskidzkiej $w$ okresie lateńskim i rzymskim, Rozprawy Habilitacyjne nr 304/1, Kraków. 
Madyda-Legutko R. 1996b. Die Púchov-Kultur in polnischen Westkarpaten. In. Z. Woźniak (ed.), Kontakte längs der Bernstrasse (zwischen Caput Adriae und den Ostseegebieten) in der Zeit um Christi Geburt, Kraków, 183-187.

Madyda-Legutko R., Poleski J. and Krąpiec M. 2005. Studia nad geografia osadnictwa w górnym dorzeczu Wisty u schytku starożytności i na poczatku średniowiecza. In. P. Kaczanowski and M. Parczewski (eds.), Archeologia o początkach Stowian, Kraków, 307-352.

Magomedov B.V. 2006. Monety iak dzherelo do istorii plemen cherniakhivs'koi kultury, Kiiv.

Magomedov B.V. 2008. Coins as a source of insight on Chernyakhiv tribes. In. A. Bursche, R. Ciołek and R. Wolters (eds.), Roman coins outside the Empire. Ways and Phases, Contexts and Functions. Proceedings of the ESF/ SCH Exploratory Workshop, Radziwitt Palace, Nieborów (Poland), 3-6 September 2005, Collection Moneta 82, Wetteren, 171-178.

Mielczarek M. 1981. Uwagi o znaleziskach monet Olbii i Pantikapajonu na obszarze Polski, Wiadomości Numizmatyczne 25, 16-28.

Mielczarek M. 1986. Znaleziska monet starożytnych z Kolomyi i jej okolic, Ukraina. Pomyt$k a$, niedoktadności, nieporozumienia, Prace i Materiały Muzeum Archeologicznego i Etnograficznego w Łodzi 6, 53-60.

Mielczarek M. 1988. O monetach greckich wybitych przed końcem I wieku p.n.e. znalezionych na obszarze Polski, Wiadomości Numizmatyczne 32, 129-158.

Mielczarek M. 1989. Ancient Greek Coins Found in Central, Eastern and Northern Europe, Wrocław.

Mielczarek M. 1996. Antyczne monety greckie odkryte na ziemiach Polski, Litwy, Białorusi $i$ zachodniej Ukrainy. In. K.Filipow, B. Kuklik (eds.), Białoruś, Litwa, Polska, Ukraina. Wspólne dzieje pieniadza, Supraśl 20-22 X 1994. Materiaty z I Międzynarodowej Konferencji Numizmatycznej, Warszawa, 31-37.

Mielczarek M. 2004. Monety greckie wybite przed końcem I w. p.n.e. znalezione nad Battykiem. In. G. Horoszko (ed.), Najnowsze badania nad numizmatyka i sfragistyka Pomorza Zachodniego. Materiaty z konferencji 50 lat Dziatu Numizmatycznego Muzeum Narodowego w Szczecinie, Szczecin, 25-36.

Mielczarek M. 2008. On Greek coin finds from the Central European Barbaricum. In. A. Bursche, R. Ciołek, R. Wolters (eds.), Roman Coins outside the Empire, Proceedings of the ESF/SCH Exploratory Workshop, Radziwitt
Palace, Nieborów (Poland), 3-6 September 2005, Collection Moneta, 82, Wetteren, 11-34.

Mielniczuk B. 1997. Skarb rzymskich denarów I-II w. n.e. z Żulic, województwo zamojskie, w Muzeum Okręgowym w Koszalinie, Koszalińskie Zeszyty Muzealne 21, 261-295.

Militký J. 2013. Nálezy řeckých, řimských a raně byzantských mincí v Čechách (5. století pred Kristem až 7. století po Kristu). Komentovaný katalog nálezového fondu, Praha.

Milutinović D. 2017. Monety prowincjonalnorzymskie aleksandryjskie w Barbaricum środkowoeuropejskim, Folia Numismatica 31/2, 159-184.

Mitkowa-Szubert K. 1989. The Nietulisko Mate hoards of Roman denarii, Warszawa.

Myzgin K. 2011. Nakhodki rimskikh monet provintsial'noi maloaziiskoi chekanki II-III vv. Na territorii chernyakhovskoi kul'tury, Drevnee Prichernomor'e IX, 321-238.

Myzgin K. 2012. Finds of Roman Coins of Asia Minor Provincial Mintage in the Territory of Chernyakhiv Culture. In. G.R. Tsetskhladze et al. (eds.), The Black Sea, Paphlagonia, Pontus and Phrygia in Antiquity Aspects of archaeology and ancient history, BAR International Series 2432, Oxford, 197-201.

Myzgin K. 2013. O nakhodke dvukh bosporskikh staterov na poselenii pozdnerimskogo vremeni Komariv (Chernovitskaya oblast') $i$ ikh vozmozhnom kul'turno-istoricheskom kontekste. In. V.N. Zin'ko (ed.), XIV Bosporskie chteniya. Bospor Kimmeriiskii $i$ varvarskii mir $v$ period antichnosti i srednevekov'ya. Arkheologicheskii ob'ekt v kontekste istorii, Kerch, 336-341.

Myzgin K. 2015a. New Finds of Roman Provincial Bronze Medallions on the Territory of Ukraine, Notae Numismaticae - Zapiski Numizmatyczne X, 103-114. DOI: 10.11588/diglit. 31074.10

Myzgin K. 2015b. O novoi nakhodke bronzovogo medal'ona Elagabala chekanki g. Philipopol'. In. И.В. Волков et al. (eds.), Vosemnadtsataya Vserossiiskaya Numizmaticheskaya konpherentsiya, Moskva-Kolomna 20-25 aprelya 2015 goda. Tezisy dokladov i soobshchenii, Moskva, 32-33.

Myzgin K. 2017. Echo of the Gothic wars: finds of Roman provincial coins (Balkan cities mintage) on the territory of Ukraine. In. M. Vojvoda (ed.), International numismatic symposium "Circulation of the antique coins in Southeastern Europe", Book of abstracts, Belgrade, 26. 
Myzgin K. 2018. Finds of Roman provincial coins on the territory of Eastern Europe: Balkan cities mintage. In. V. Ivanišević, B. Borić-Brešković and M. Vojvoda (eds.), Proceedings of the International Numismatic Symposium Circulation of the antique coins in Southeastern Europe, Belgrade, 87-103.

Myzgin K. and Beidin G. 2012. Finds of Bosporan Coins in the Territory of the East-European Barbaricum, Notae Numismaticae - Zapiski Numizmatyczne VII, 57-91. DOI: 10.11588/ diglit.22230.9

Myzgin K. and Beidin G.V. 2015. O pozdnebosporskikh monetakh na territorii Barbarikuma. In. И.В. Волков et al. (eds.), Vosemnadtsataya Vserossiiskaya Numizmaticheskaya konpherentsiya, Moskva-Kolomna 20-25 aprelya 2015 goda. Tezisy dokladov i soobshchenii, Moskva, 30-32.

Nosek S. 1957. Materiaty do badań nad historia starożytna $i$ wczesnośredniowieczna międzyrzecza Wisty i Bugu, Annales Universitates Mariae Curie-Skłodowska F/VI, Lublin.

Ondrouch V. 1964. Nálezy keltských, antických a byzantských minci na Slovensku, Bratislava.

Opozda T. 1970. Nowe znaleziska monet rzymskich, Wiadomości Numizmatyczne 14, 5152.

Piotrowicz L. 1928-1929. Monety rzymskie znalezione $w$ Krakowie, Wiadomości Numizmatyczno-Archeologiczne 12, 52-56.

Piotrowicz L. 1931-1932. Monety starożytne w Regjonalnem muzeum Podolskiem T. S. L. $w$ Tarnopolu, Wiadomości Numizmatyczno-Archeologiczne 14, 124-125, Nos. 1-13.

Piotrowicz L. 1936. Znaleziska monet greckich i rzymskich przy budowie kolei matopolskich, Wiadomości Numizmatyczno-Archeologiczne 18, 95-109.

Paszkiewicz B. 1999. Jeszcze dwa fragmenty skarbu monet rzymskich z Żulic, Wiadomości Numizmatyczne 43/1-2, 99-114.

Paszkiewicz B. 2000. Znaleziska monet zarejestrowane w Katedrze Archeologii UMCS w 1999r., Fontes Numismatici I, 9-74.

Paszkiewicz B. 2005. Skarb z Żulic (1970) bez końca. In. P. Łuczkiewicz, M. Gładysz-Juścińska, M. Juściński, B. Niezabitowska and S. Sadowski (eds.), Europa barbarica. (Ćwierć wieku archeologii w Mastomęczu, Monumenta Studia Gothica 4), Lublin, 369-373.

Roczkalski B. and Włodarczak P. 2005-2006. Badania wykopaliskowe przeprowadzone w latach 2005-2006 na stanowisku 4 w Eysokaniach oraz na s. 33 w Brzeziu, Raport, 359-369.
Romanowski A. 2008. Die fundmünzen der Römischen zeit in Polen, Rechtsufriges Masovien und Podlachien, Collection Moneta 84, Warsaw.

Rudnicki M. 2014. Znaleziska. Jakuszowice, gm. Kazimierza Wielka, pow. kazimierski, Wiadomości Numizmatyczne 58/1-2, 276-278.

Salamon M. 1971. The Chronology of Gothic Incursions into Asia Minor in the IIIrd century $A D$, EOS 59, 109-139.

Sidarovich V.M. 2013. A hoard of Alexandrian Tetradrachms from Last Quarter of the 3rd Century AD found in the Upper Neman Region, Notae Numismaticae - Zapiski Numizmatyczne VIII, 173-183. DOI: 10.11588/diglit.31072.17.

Sidarovich V.M. 2014. The Finds of Greek and Roman Coins in Belarus, Notae Numismaticae Zapiski Numizmatyczne IX, 71-96. DOI: 10. 11588/diglit.31073.9.

Skowronek S. 1973. Glinik Mariampolski, pow. Gorlice. Skarb monet bosforańskich $i$ olbijskich, Wiadomości Numizmatyczne 17/3, 154-155.

Wagner T. and Zając B. 2018. A new Roman coin finds from Częstochowa region, Notae Numismaticae - Zapiski Numizmatyczne XIII, 225-243.

Wielowiejski J. 1960. Przemiany gospodarczo-społeczne u ludności poludniowej Polski w okresie późnorzymskim i przedrzymskim, Materiały Starożytne 6, Warszawa.

Wolters R. 1999. Nummi signati. Untersuchungen zur römischen Münzprägungen und Geldwirtschaft, Vestigia. Beiträge zur alten Geschichte 49, München.

Vakulenko L.V. 2010. Ukrainski Karpaty u nizn'orims'kii chas (etnokul'turni ta sotsial'no-ekonomichni prot-sesu), Kiiv.

Vojvoda M. 2017. Coins of the Viminacium Mint from the Pecine Necropolis (Viminacium), Archaeology and Science 12, 51-74.

Zając B. 2017. Circulation of Trajan's silver Greek imperial coins struck in Lycia and Cappadocia in the light of coin finds in Europe. In. M. Caccamo Caltabiano et al. (eds.), $X V$ International Numismatic Congress Taormina 2015 Proceedings, Taormina, 967-970.

Zapolska A. 2008. Römische Münzen im Westbaltischen Kulturkreis - Kontexte und Funktionen. In. A. Bursche, R. Ciołek and R. Wolters (eds.), Roman coins outside the Empire. Ways and Phases, Contexts and Functions. Proceedings of the ESF/SCH Exploratory Workshop, Radziwitt Palace, Nieborów 
(Poland), 3-6 September 2005, Collection Moneta 82, Wetteren, 179-194.

Zapolska A. 2011. Roman Coins from the Western Part of the West Balt Territory. In. N. Holmes (ed.), Proceedings of the XIVth International Numismatic Congress Glasgow 2009, Glasgow, 1115-1125.

Zapolska A. 2013. The Influx of Roman Coins to the West Balt Culture Environment, Notae Numismaticae - Zapiski Numizmatyczne VIII, 105-123. DOI: $10.11588 /$ diglit.31072.13

Zapolska A. 2014. Monety rzymskie z cmentarzyska płaskiego w Łężanach. In. A. Wiśniewska (ed.), Lęzany. Cmentarzysko z okresu wptywów rzymskich $i$ wędrówek ludów na Pojezierzu Mragowskim. Badania w sezonie 2013, Warszawa, 79-101.
Jarostaw Bodzek, ORCID 0000-0002-4272-4117 Jagiellonian University Institute of Archaeology jaroslaw.bodzek@uj.edu.pl

Szymon Jellonek, ORCID 0000-0001-6500-3286 Jagiellonian University Institute of Archaeology sjellonek@gmail.com

Barbara Zajac ORCID 0000-0003-4731-5782 Jagiellonian University Institute of Archaeology basia.zajac21@gmail.com 